Article

\title{
Engineering Study of a Pilot Scale Process Plant for Microalgae-Oil Production Utilizing Municipal Wastewater and Flue Gases: Fukushima Pilot Plant
}

\author{
Nugroho Adi Sasongko ${ }^{1,2, *}$, Ryozo Noguchi ${ }^{3, *}$, Junko Ito ${ }^{4}$, Mikihide Demura ${ }^{4}$, \\ Sosaku Ichikawa ${ }^{3}$, Mitsutoshi Nakajima ${ }^{4}$ and Makoto M. Watanabe ${ }^{4}$ \\ 1 Graduate School of Life and Environmental Sciences, University of Tsukuba, 1-1-1 Tennodai, \\ Tsukuba, Ibaraki 305-8572, Japan \\ 2 Agency for The Assessment and Application of Technology (BPPT), Jakarta 10340, Indonesia \\ 3 Faculty of Life and Environmental Sciences, University of Tsukuba, 1-1-1 Tennodai, \\ Tsukuba, Ibaraki 305-8572, Japan; ichikawa.sosaku.fn@u.tsukuba.ac.jp \\ 4 Algae Biomass and Energy System R\&D Center, University of Tsukuba, 1-1-1 Tennodai, \\ Tsukuba, Ibaraki 305-8572, Japan; ito.junko.ga@u.tsukuba.ac.jp (J.I.); demura.mikihide.fw@u.tsukuba.ac.jp (M.D.); \\ nakajima.m.fu@u.tsukuba.ac.jp (M.N.); watanabe.makoto.ga@u.tsukuba.ac.jp (M.M.W.) \\ * Correspondence: nugroho.adi@bppt.go.id (N.A.S.); noguchi.ryozo.gm@u.tsukuba.ac.jp (R.N.); \\ Tel.: +81-(0)29-853-4697 (R.N.)
}

Received: 16 May 2018; Accepted: 15 June 2018; Published: 28 June 2018

\begin{abstract}
This article presents an engineering study of an integrated system to produce bio-oil from microalgae biomass. The analysis is based on a pilot plant located at Minami-soma Fukushima, Japan, which further simulates 1 ha based-cultivation. Municipal wastewater and flue gases were utilized as nutrient sources for the microalgae culture of the proposed design. A flow sheet diagram of the integrated plant was synthesized by process engineering software to allow simulation of a continuous system. The design and sizing of the process equipment were performed to obtain a realistic estimation of possible production cost. The results demonstrated that nutrient savings was achieved by wastewater and $\mathrm{CO}_{2}$ utilization to the polyculture of native microalgae. Process simulation gave an estimated $\mathrm{CO}_{2}$ sequestration of 82.77 to 140.58 tons ha ${ }^{-1}$ year $^{-1}$ with 63 to 107 tons ha $^{-1}$ year $^{-1}$ of potential biomass production. The integrated process significantly improved the energy balance and economics of biofuel production and also the wastewater treatment plant (WWTP). The economic analysis confirmed that higher biomass production and technology improvement were required to achieve operational feasibility and profitability of the current microalgae-based bio-oil production.
\end{abstract}

Keywords: engineering design; energy balance; $\mathrm{CO}_{2}$ emission; microalgae oil; municipal wastewater; process simulation

\section{Introduction}

Microalgae cultivation requires significant quantities of energy, water, and nutrients for growth during the production cycle. The main nutritional requirements for microalgae growth are nitrogen, phosphorous, and micronutrients including potassium [1]. Microalgae take up these nutrients along with $\mathrm{CO}_{2}$ and produce biomass via photosynthesis. Various combinations of fertilizers may be used, including common field crop Nitrogen-Phosphorus-Potassium (NPK) fertilizer, but the associated costs can sometimes exceed the value of the final microalgae products [2]. Cultivation inputs must be inexpensive and of low environmental impact, allowing for the economical mass production of feedstock for microalgae biofuels to achieve technical and economic feasibilities and also to be sustainably produced. 
In recent years, the potential use of wastewater as a nutrient feedstock for microalgae-based fuel production has received considerable attention [3-7]. Wastewater was found as a convenient and cheap source of nutrients for microalgae growth. Typically, the C:N ratios for municipal wastewaters are ranging from 3:1 to 4:1 compared with those of microalgae biomass (typically 6:1, ranging from 10:1 to 5:1 depending on whether $\mathrm{N}$ is limiting or not [8,9]. Thus, domestic wastewaters contain insufficient $\mathrm{C}$ to remove all the $\mathrm{N}$ (and $\mathrm{P}$ ) by direct assimilation into microalgae biomass. Therefore, nutrients ratio adjustments with additional carbon and nitrogen sources such as flue gases and $\mathrm{N}$ fertilizers are necessary. Since microalgae are known to grow well in wastewater $[10,11]$, a possible synergistic solution is to co-locate and integrate microalgae production with the treatment of nutrient-rich wastewater and utilization of $\mathrm{CO}_{2}$ from power plant flue gases. This coupling of wastewater treatment with $\mathrm{CO}_{2}$ sequestration and biofuel production is considered to be economically viable as costs associated with microalgae production and harvest are part of the wastewater treatment cost, essentially producing low-cost feedstock for biofuel production [12]. This approach principally reduces the cost of microalgae production, while preventing eutrophication and mitigating $\mathrm{CO}_{2}$ emissions. Microalgae-based biofuel production by utilized wastewater has been assumed to have smaller environmental footprint compared to commercial fresh water cultivation technique [4], having a significantly less environmental impact regarding water footprint, energy and fertilizer use, and residual nutrient removal from spent-growth medium prior discharge to avoid eutrophication of receiving waters. Commercial microalgae farms require sources of water, nutrients and carbon dioxide which contribute to $10-30 \%$ of total production costs [13-15].

Particularly in Japan, many wastewater treatment plants (WWTPs) are facing pressure to improve effluent quality to meet the Japan Sewage Discharge Standard [16]. This means that secondary effluent should not exceed the threshold of chemical oxygen demand (COD) $25 \mathrm{mg} \mathrm{L}^{-1}$, biological oxygen demand (BOD) $25 \mathrm{mg} \mathrm{L}^{-1}$, ammonium $5 \mathrm{mg} \mathrm{L}^{-1}$, total nitrogen (TN) $40 \mathrm{mg} \mathrm{L}^{-1}$, total phosphorous (TP) $4 \mathrm{mg} \mathrm{L}^{-1}$, suspended solid (SS) $50 \mathrm{mg} \mathrm{L}^{-1}$ and $\mathrm{pH}$ standard limitation value between 5.8-8.6.

The primary municipal wastewater treatment plant (MWWTP) and secondary treatment by activated sludge is most energy and cost consuming process. Thus, if primary treated wastewater can be purified by microalgae to be able to be discharged to the natural environment, saved energy and cost would give significant advantages for LCA and economy of microalgae-oil production.

However, there are some challenges in cultivating microalgae in wastewater, including unbalanced $\mathrm{N} / \mathrm{P}$ ratio, the presence of bacterial contamination and competitors, low biomass density and lipid content, and incomplete removal of nutrients [8,9]. Nevertheless, these studies effectively demonstrate that wastewaters can be an excellent medium for biomass production and lipid accumulation and that nitrogen and phosphorus are also removed from wastewaters. The physical and chemical characteristics of municipal wastewater from primary treatment plant entirely different from those of anaerobic digestion effluent, industrial wastewater, and agricultural wastewater.

Moreover, lack of the practical information on the harvesting technique from microalgae based wastewater cultivation inhibits the scale up of harvesting method to the large commercial scale of integrated cultivation. Easy and simple harvesting technique and lower downstream production cost are necessary to establish an efficient integrated system. It is essential to reduce the total combined cost of these processes through some technical developments. The cost for microalgae harvesting is as high as $20 \%$ of the total production cost of bio-oil, although it varies based on the type of harvest technology used and the density of the microalgae culture [17]. Also, the typically small size of a microalgae cell (less than $10 \mu \mathrm{m}$ in diameter) in a diluted culture medium (less than $2.0 \mathrm{~g} \mathrm{~L}^{-1}$ ) and a density similar to that of water make microalgae harvesting one of the key bottlenecks for the production of bio-oil from microalgae [18]. As shown in Figure 1, the density of microalgae is close to that of water and salt water at $1025 \mathrm{~kg} \mathrm{~m}^{-3}$, therefore there is little density difference driving microalgae settlement [17-19]. Nonpolar lipids such as triacylglyceride (TAG) and free fatty acids (FFA) tend to float to the surface of water phase due to the lighter density compared to water. Thus, microalgae cell with higher content of lipid will be difficult to settling [20]. 


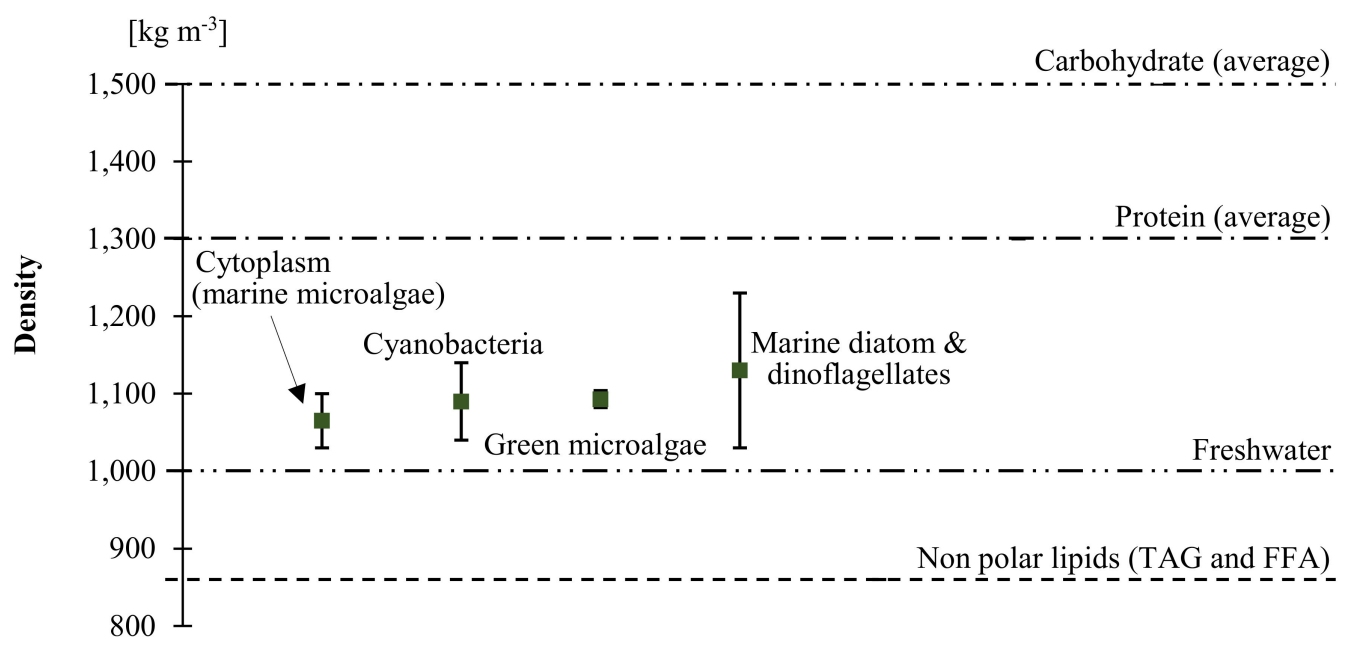

Figure 1. Variation of microalgae biomass density relatives to water and various substances [21-25].

Furthermore, increasing the oil extraction efficiency from microalgae biomass is also a challenging issue to achieve the feasibility of biofuel production. In a conventional method, produced bio-crude which mostly contain TAGs can be extracted by using a dry method [26]. Meanwhile, another prospective method is a hydrothermal liquefaction (HTL) [27,28], where the wet process pathway yields a positive energy balance by avoiding the drying step and produces bio-crude. In this research, authors presumed the wet extraction route would be preferable with primary component of hydrocarbons further to be converted into transportation fuels. It is necessary to develop a novel integrated process system that achieves low energy input for bio-oil production from microalgae. Moving forward, to ultimately achieve cost goals and reduce uncertainty in key areas for the microalgae production and processing pathway in the context of a fully integrated process with downstream conversion, some important bottlenecks, uncertainties, and areas for further development need to be discussed. The production of bio-oil from microalgae biomass is a sequential process that consists of the cultivation, harvest and dehydration, lipid and hydrocarbon extraction, and conversion into advanced biofuels.

There are very limited reports on real pilot plant case studies of microalgae-oil production utilizing municipal wastewater and flue gases. Therefore, in this study, we aimed to identify the essential issues of integrated process system of native microalgae communities for bio-oil production in a local municipal wastewater treatment plant. This research also attempted to observe the key physical parameters to estimate mass balance, nutrients and energy efficiency and potential GHG emission reduction for the similar productivities in a freshwater cultivation, by replacing the artificial fertilizers. It was desired to optimize processes by combining the strengths of several different upstream and downstream processing techniques. The research developed a systematic approach for the alternative process paths and performed a techno-economic analysis to determine the optimum design.

The investigation is very important since it is a first full case study based on a real integrated microalgae system pilot plant located in northern Japan which has a temperate climate condition. The experience and success story are expected to serve as an appropriate benchmark for continued research leading to a large scale implementation.

\section{Materials and Methods}

\subsection{Methodology Framework}

This research identified a viable opportunity to utilize municipal wastewater and industrial flue gases to adjust nutrients balance during cultivation. Several process scenarios were constructed to analyze the pathways from cultivation to biofuel production. The whole process design consists of several unit operations which are interconnected by input and output streams. The main results 
of the model are potential nutrients substitution for the culture including the necessary amount of external flue gases (particularly $\mathrm{CO}_{2}$ ), material, and energy demand of the proposed integrated process. The results from the model can be used to evaluate different process options which are described in the next section.

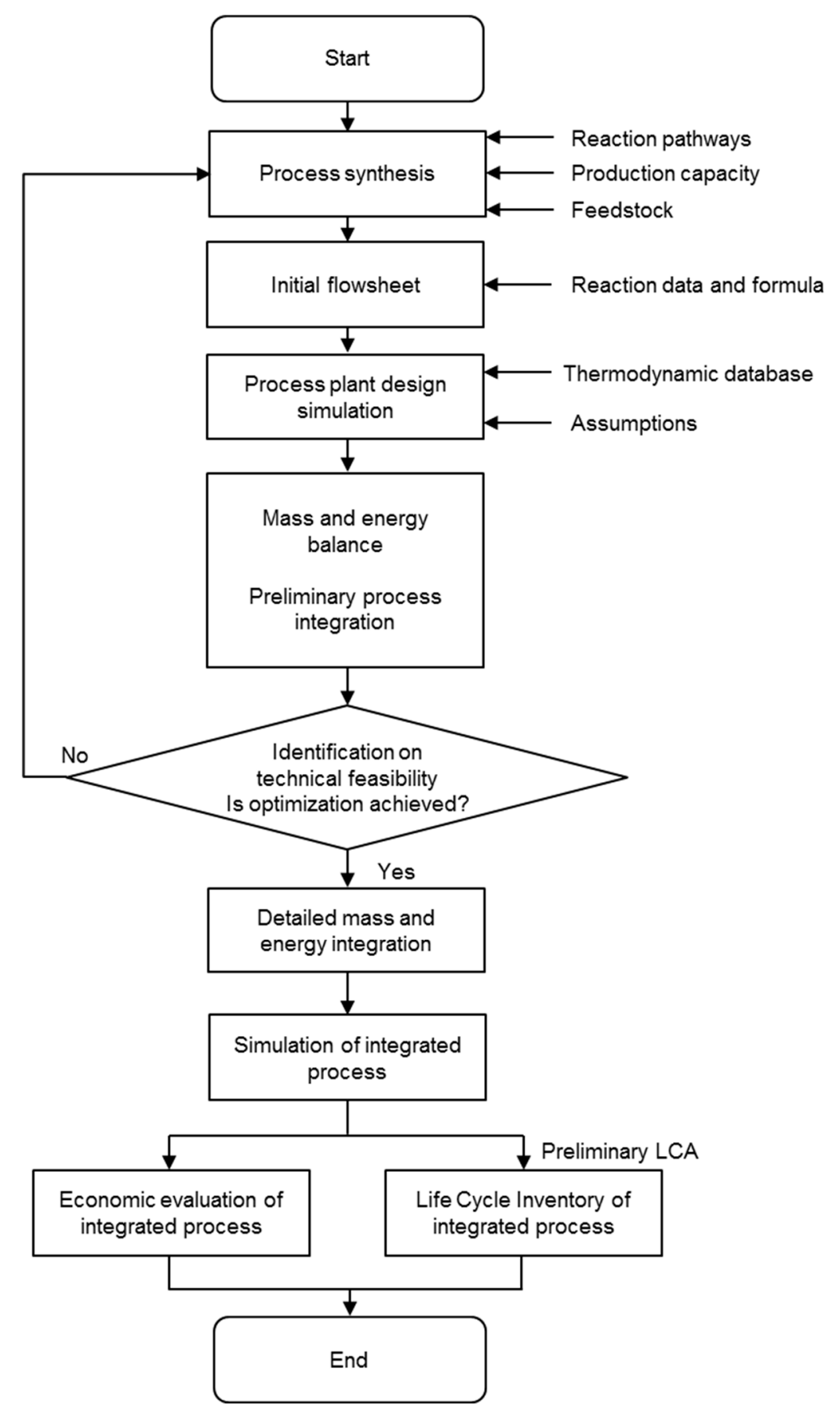

Figure 2. Flow chart of engineering design approach for microalgae bio-oil production.

Figure 2 shows the flow chart of engineering design approach for microalgae bio-oil production. The input to the unit processes consisted of a set of physical values, e.g., mass flow, temperature, and concentration of different substances and used to calculate the output stream. The unit operations contain equations and data which were used to derive the output stream from the input. It is also 
possible to use several input streams and construct a set of outputs. Two primary outputs were analyzed here, techno-economic analysis and preliminary life cycle assessment (LCA). The economic evaluation was calculated to understand the initial cost and operational cost of the proposed system, including analysis of the production cost for bio-crude. Meanwhile, life cycle inventory (LCI) of the integrated process was assessed to analyze the total GHG emission.

\subsection{Process Simulation}

The native microalgae culture in Minami-soma, Fukushima, Japan to produce biofuel was investigated, and the process plant design was simulated. Superpro Designer 9.0 ${ }^{\circledR}$ (Intelligent, Inc. ${ }^{\circledR}$, Scotch Plains, NJ, USA) and SIMAPRO 8.1.1 ${ }^{\circledR}$ (PRé Consultants B.V., Amersfoort, The Netherlands) coupled with the Ecoinvent database $3.1^{\circledR}$ (ecoinvent. Zürich, Switzerland) were used to design the process and calculate complex energy and material balances, including environmental inventories. The initial stage of process plant design and LCA were successfully developed. The overall system was composed of two main sections: an upstream processing section which is targeted to the potential municipal wastewater utilization, $\mathrm{CO}_{2}$ sequestration from flue gases, microalgae culture (biomass and lipids production) and also a downstream processing section which includes the harvesting, extraction, and pre-treatment of the bio-crude. For each operation within a unit procedure, the simulator performed material and energy balance and equipment sizing evaluation. The pilot plant experiment information was used for designing the flow sheet.

\subsubsection{Cultivation Pond Section}

We found that native microalgae communities (dominant species: Desmodesmus spp. and Scenedesmus spp.) cultivated in Minami-soma, Fukushima have a cell diameter range between 25 to $100 \mu \mathrm{m}$. Minami-soma city belongs to the Tohoku region in Japan, a relatively northern part of Japan. Minimum water temperature was $-1{ }^{\circ} \mathrm{C}$ until $0.9^{\circ} \mathrm{C}$ from December 2014 to March 2015. Average water temperatures ranged from $7{ }^{\circ} \mathrm{C}$ in December and January to $25^{\circ} \mathrm{C}$ in July and August. As shown in Figure 3, average day time of photon flux density ranged from $307 \mu \mathrm{mol} \mathrm{m}^{-2} \mathrm{~s}^{-1}$ in December to $540 \mu \mathrm{mol} \mathrm{m}{ }^{-2} \mathrm{~s}^{-1}$ in May and the maximum from approximately $960 \mu \mathrm{mol} \mathrm{m}{ }^{-2} \mathrm{~s}^{-1}$ in December to $2000 \mu \mathrm{mol} \mathrm{m}^{-2} \mathrm{~s}^{-1}$ in May [29]. Data of dynamic weather condition that influence biomass productivity of autotroph microalgae from December 2014 until December 2016 in Fukushima was taken from Local weather station [30].

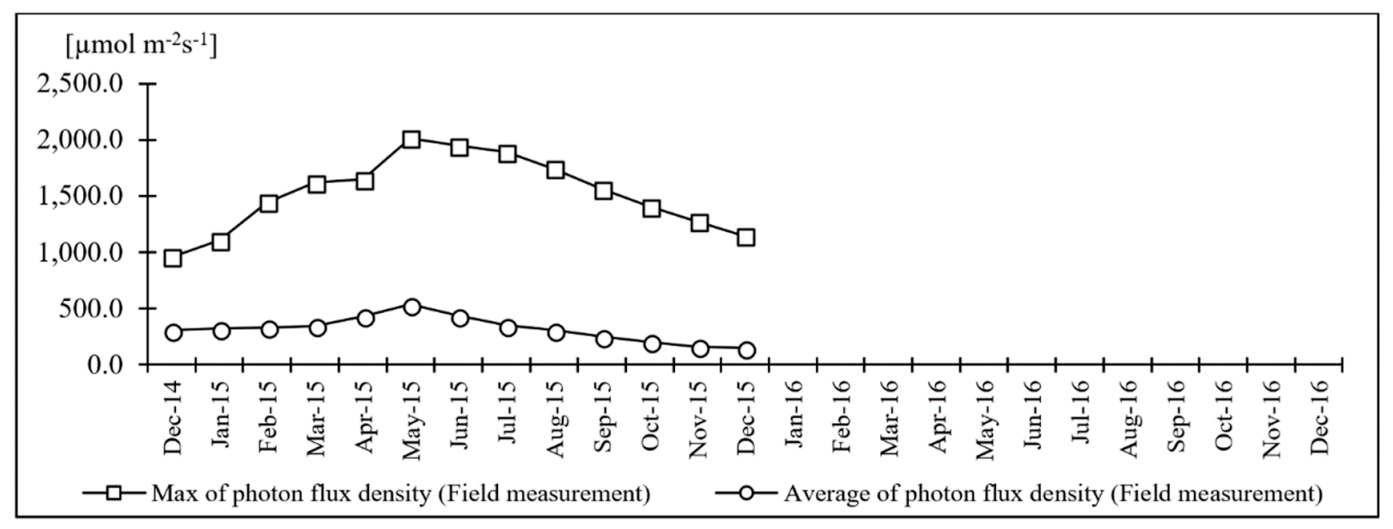

(a)

Figure 3. Cont. 


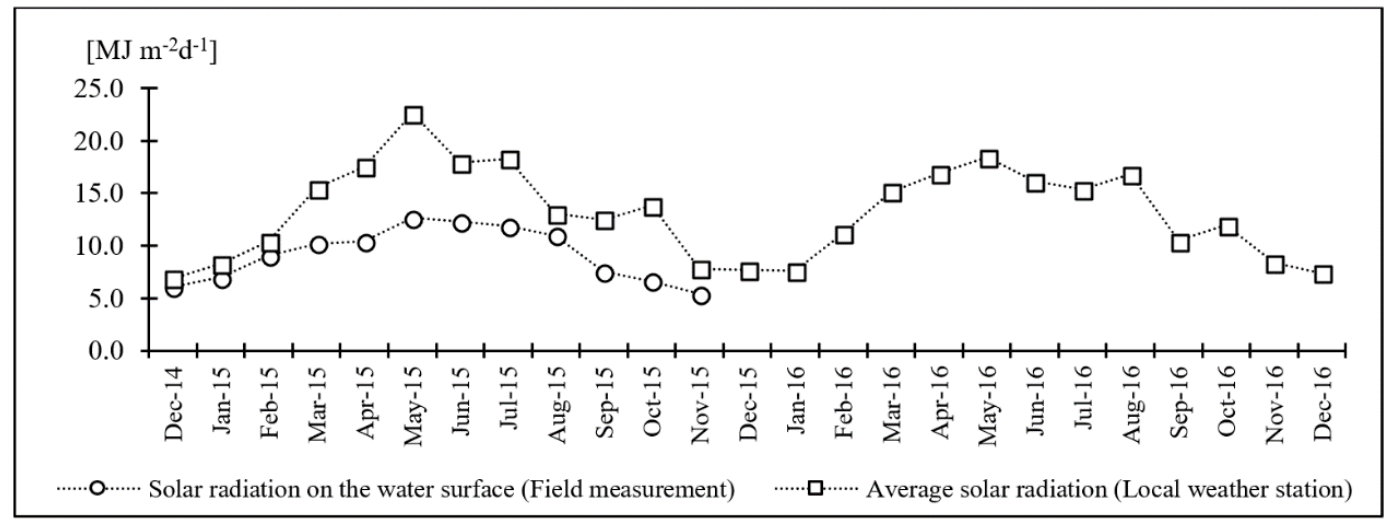

(b)

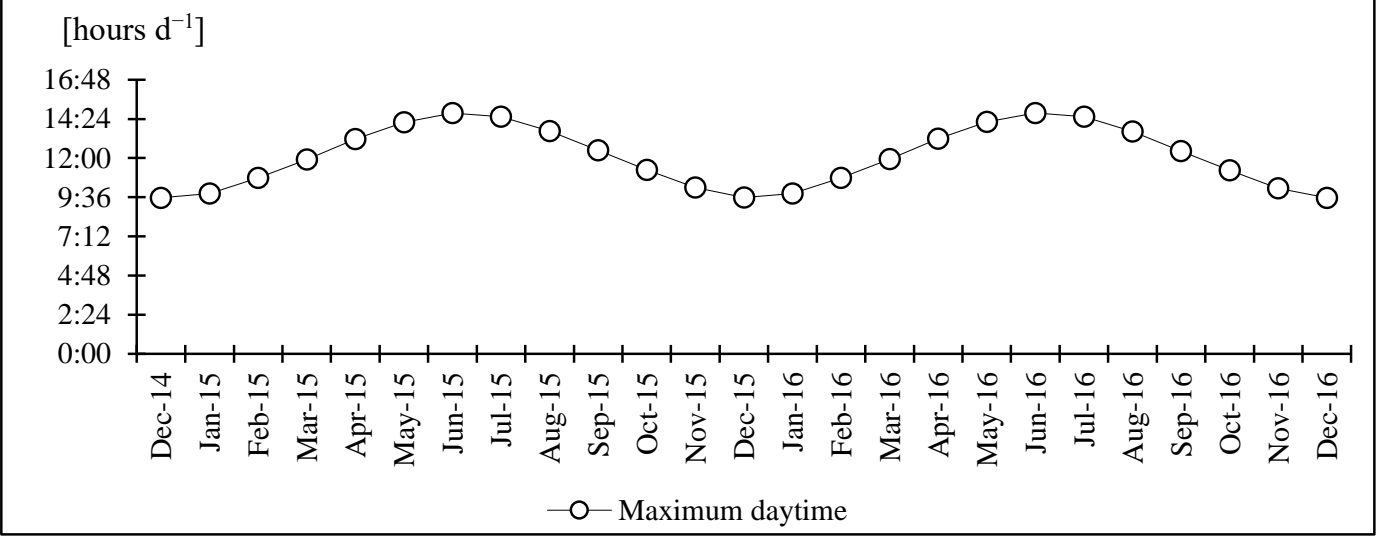

(c)

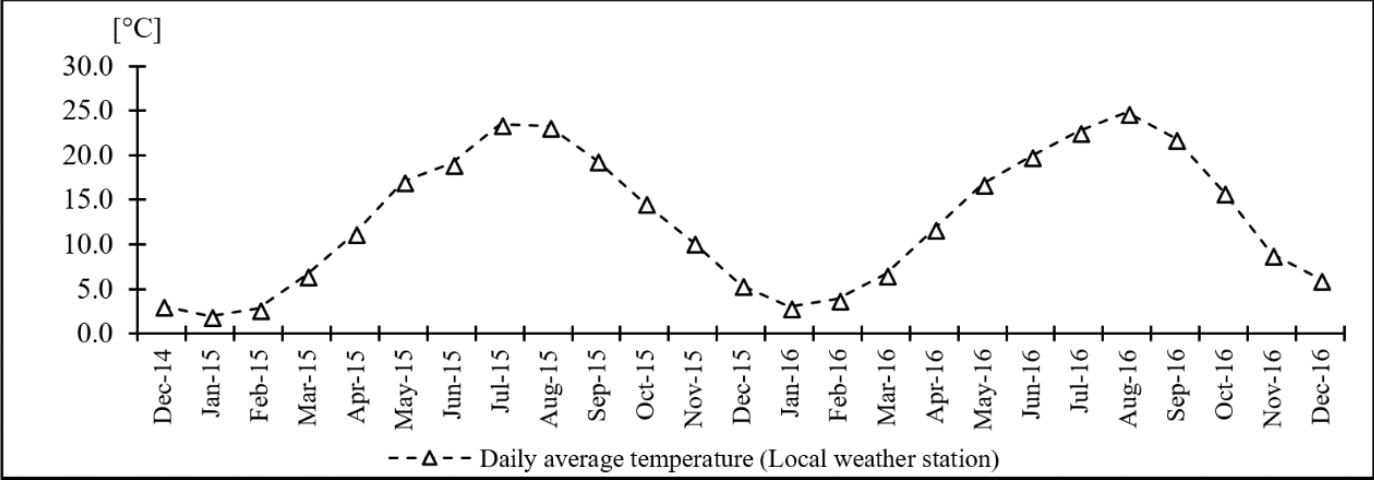

(d)

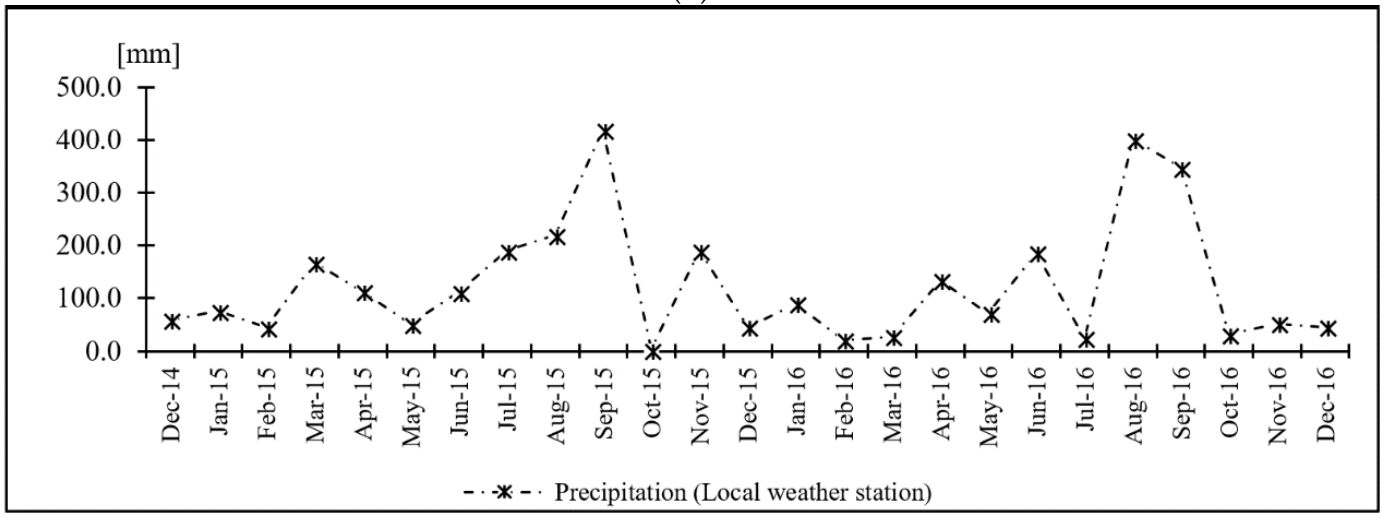

(e)

Figure 3. Monthly weather condition at Minami-soma city, Fukushima, Japan (a) photon flux density; (b) solar radiation; (c) maximum daytime; (d) daily average temperature; (e) precipitation. 
The hydraulic retention time (HRT) of the water and harvesting period in the cultivation ponds was between 4-7 days. An aerobic bio-oxidation pond type was constructed as a demonstration scale culture which also corresponded to the previous reports [8,9]. The initial constructed microalgae pond had an area size of $1000 \mathrm{~m}^{2}(20 \mathrm{~m} \times 50 \mathrm{~m})$ with $0.3-0.4 \mathrm{~m}$ of water depth and was equipped with paddlewheels. Further, ten identical open ponds were replicated and run in parallel for 1 ha of proposed cultivation area. Each pond is presumed in operation for $350 \mathrm{~d} \mathrm{y}^{-1}\left(8400 \mathrm{~h} \mathrm{y}^{-1}\right)$ and 15 days off for maintenance, annually.

In the initial stage, we conducted a freshwater culture experiment. A synthetic mixed fertilizer (Medium K) was repeatedly added to balance the nutrient ratio. We modified the nutrient composition from [31] to provide appropriate essential nutrients for microalgae growth. The additional nutrients also included sodium acetate $\left(\mathrm{CH}_{3} \mathrm{COONa}\right)$ by a concentration as high as $0.18 \mathrm{mg} \mathrm{L}^{-1}$, diammonium phosphate (DAP) $12.4 \mathrm{mg} \mathrm{L}^{-1}$ and nitrogen (as nitrate) $207 \mathrm{mg} \mathrm{L}^{-1}$ which were fed in from raw material storage tanks through hoppers. The details of the modified nutrients (Medium K) for the freshwater cultivation ponds is listed in Table 1. Preliminary continuous field measurements showed that total soluble (TS) mineral in the cultivation ponds was approximately $278.1 \mathrm{mg} \mathrm{L}^{-1}$. This information is essential to define the initial condition of the simulated cultivation ponds.

Table 1. Artificial nutrients in freshwater cultivation ponds.

\begin{tabular}{|c|c|c|c|c|c|}
\hline $\begin{array}{c}\text { Medium K } \\
\text { Reagent List }\end{array}$ & $\begin{array}{l}\text { Concentration of } \\
\text { Selected Nutrients }\end{array}$ & $\underset{\left[\mathrm{mg} \mathrm{L}^{-1}\right]}{\operatorname{Medium~K}}$ & $\begin{array}{l}\text { Unit Cost } \\
\left.\text { [JPY } \mathrm{g}^{-1}\right]\end{array}$ & $\begin{array}{l}\text { Cultivation Cost } \\
\left.\text { [JPY ha }{ }^{-1} 7 d^{-1}\right]\end{array}$ & $\begin{array}{c}\text { Total } \\
{\left[\mathrm{JPY} \mathbf{h a}^{-1} \mathbf{y}^{-1} \text { ] }\right.}\end{array}$ \\
\hline $\begin{array}{c}\text { Commercially supplied } \\
\text { fertilizer liquid } \\
\text { (Megasoru } 2 \text { gou }{ }^{\circledR} \text { ) }\end{array}$ & $\begin{array}{c}\mathrm{N}: 0.11(\mathrm{TN} 11.0 \% \\
\mathrm{NO}_{3}{ }^{-} \mathrm{N} 9.50 \% \\
\left.\mathrm{NH}_{4}{ }^{-} \mathrm{N} 1.50 \%\right) \\
\mathrm{P}: 0.09 \times 0.44 \\
\left(\mathrm{P}_{2} \mathrm{O}_{5}: 142.00 \mathrm{~g} \mathrm{~mol}^{-1}\right. \\
9.00 \%)\end{array}$ & 55.00 & 0.564 & 93,060 & $4,852,414$ \\
\hline $\begin{array}{l}\text { Potassium nitrate } \\
\qquad\left(\mathrm{KNO}_{3}\right)\end{array}$ & $101.10 \mathrm{~g} \mathrm{~mol}^{-1}, \mathrm{~N}: 0.14$ & 25.00 & 3.330 & 249,750 & $13,022,679$ \\
\hline $\begin{array}{c}\text { Ammonium nitrate } \\
\left(\mathrm{NH}_{4} \mathrm{NO}_{3}\right)\end{array}$ & $80.00 \mathrm{~g} \mathrm{~mol}^{-1}, \mathrm{~N}: 0.35$ & 9.50 & 3.780 & 107,730 & $5,617,350$ \\
\hline $\begin{array}{c}\text { Magnesium sulfate } \\
\text { heptahydrate } \\
\left(\mathrm{MgSO}_{4} \cdot 7 \mathrm{H}_{2} \mathrm{O}\right)\end{array}$ & $246.47 \mathrm{~g} \mathrm{~mol}^{-1}$ & 7.00 & 1.890 & 39,690 & $2,069,550$ \\
\hline $\begin{array}{c}\text { Magnesium sulfate } \\
\text { hexahydrate } \\
\left(\mathrm{MgSO}_{4} \cdot 6 \mathrm{H}_{2} \mathrm{O}\right)\end{array}$ & $228.46 \mathrm{~g} \mathrm{~mol}^{-1}$ & 57.15 & 4.770 & 817,817 & $42,643,289$ \\
\hline $\begin{array}{c}\text { Calcium nitrate } \\
\text { tetrahydrate } \\
\left(\mathrm{Ca}\left(\mathrm{NO}_{3}\right)_{2} \cdot 4 \mathrm{H}_{2} \mathrm{O}\right)\end{array}$ & $164.10 \mathrm{~g} \mathrm{~mol}^{-1} \mathrm{~N}: 0.17$ & 58.00 & 3.600 & 626,400 & $32,662,286$ \\
\hline $\begin{array}{c}\text { EDTA Fe } \\
\left(\mathrm{C}_{10} \mathrm{H}_{13} \mathrm{FeN}_{2} \mathrm{O}_{8}\right)\end{array}$ & $345.07 \mathrm{~g} \mathrm{~mol}^{-1}$ & 2.00 & 1.150 & 5865 & 305,818 \\
\hline TOTAL COST & & & & $1,940,312$ & $101,173,385$ \\
\hline
\end{tabular}

In the second stage, which is a process simulation, we proposed the municipal wastewater to be an option for replacing the artificial nutrients sources to the cultures. A primary MWWTP of Kasima at Minami-soma city was intended to supply water and nutrients for microalgae culture and was analyzed to see its substitution potential for the synthetic fertilizers. The material balance was performed based on chemical components such as COD, BOD, TOC, TN, and TP. Table 2 shows the average values of the initial nutrients' composition from the primarily treated municipal wastewater, including the primarily treated wastewater from Japanese MWWTP average. We have analyzed the chemical composition of the Kashima MWWTP at Minami-soma during 2015-2016 and found that it is hypochlorite-sterilized and filtered wastewater that resembles primarily treated wastewater. The selected MWWTP at Kashima, has an average of primary treated effluent about $877 \mathrm{~m}^{3} \mathrm{~d}^{-1}$ and has been estimated capable of supplying water (and nutrients) for microalgae cultivation of more than 
1 ha size. The available organic components were critical for the initial nutrient balance for integrated wastewater treatment with microalgae cultivation ponds [32,33]. We found that the average daily TN and TP concentration from the existing sewage treatment plant at Minami-soma were $42.7 \mathrm{mg} \mathrm{L}^{-1}$ and $5.8 \mathrm{mg} \mathrm{L}^{-1}$, respectively.

Table 2. Nutrients composition from primary MWWTP.

\begin{tabular}{|c|c|c|c|c|}
\hline \multirow[t]{2}{*}{ Parameter } & \multirow[t]{2}{*}{$\begin{array}{l}\text { (1) } \\
\text { Tolerable Limit for } \\
\text { MWWTP in Japan * } \\
\quad\left[\mathrm{mg} \mathrm{L}^{-1}\right]\end{array}$} & \multicolumn{2}{|c|}{$\begin{array}{c}(2) \\
\text { Minami-Soma } \\
\text { (Primary MWWTP) } \\
\text { 2015/2016 } \\
{\left[\mathrm{mg} \mathrm{L}^{-1}\right]}\end{array}$} & \multirow[t]{2}{*}{$\begin{array}{c}\text { (3) } \\
\text { Supernatant from } \\
\text { Dehydration Process } \\
{\left[\mathrm{mg} \mathrm{L}^{-1}\right]}\end{array}$} \\
\hline & & 2015 & 2016 & \\
\hline TOC & - & - & - & - \\
\hline COD & 160.0 & 137.0 & 139.0 & 10.40 \\
\hline BOD & 160.0 & 217.0 & 214.0 & - \\
\hline $\begin{array}{c}\text { VFA (volatile fatty acid } \\
\text { as acetate) }\end{array}$ & 30.0 & - & - & - \\
\hline $\mathrm{TN}$ & 120.0 & 42.7 & 37.4 & 0.72 \\
\hline $\begin{array}{c}\text { Nitrate }+ \text { Nitrite } \mathrm{N} \\
\mathrm{NO}_{3}^{-}\end{array}$ & 0.2 & - & - & 0.36 \\
\hline $\mathrm{TP}$ & 16.0 & 5.8 & 6.3 & 0.03 \\
\hline $\mathrm{PO}_{4}{ }^{3-}$ & 10.0 & - & - & 0.04 \\
\hline TSS & 200.0 & 211.0 & 207.0 & 290.00 \\
\hline VSS & 320.0 & - & - & 85.00 \\
\hline $\mathrm{pH}$ & 7.3 & 7.3 & 7.2 & 10.60 \\
\hline
\end{tabular}

* The values presented are valid for wastewater flows higher than 100,000 of population equivalent (PE). Total phosphorus and nitrogen values only apply to discharges to sensitive waters [29].

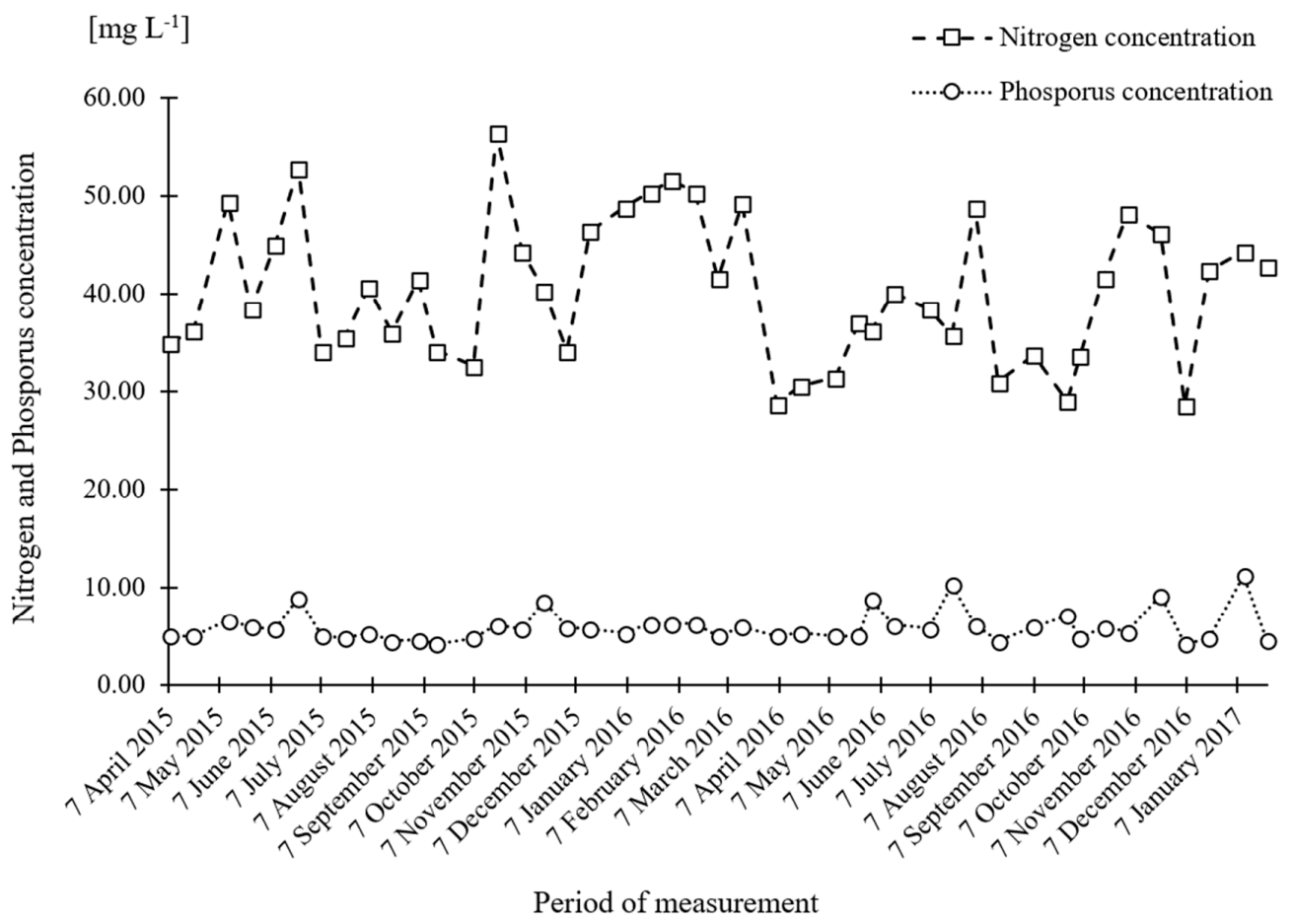

Figure 4. Continuous monthly measurement of nitrogen and phosphorus concentration at Minami-soma primary MWWTP. 
Meanwhile, there is a standard requirement for discharging the urban WWTP in Japan. According to the latest revision to the national wastewater treatment standard promulgated by the Ministry of the Environment of Japan, associated nitrogen compounds of $120.0 \mathrm{mg} \mathrm{L}^{-1} \mathrm{~d}^{-1}$ was set an average limit for municipal wastewater [34,35]. Figure 4 shows the data of ammonia and phosphorus concentration from annual continuous measurement of the Minami-soma municipal wastewater treatment plant before discharge to the ambient water bodies.

Maintaining stability of the ammonia concentration is a critical issue in continuous running of microalgae cultivation due to dynamic changes of the environmental conditions by ammonia volatilization from microalgae ponds and the need to keep the concentration of ammonium low in the water to prevent microalgae growth inhibition. An analysis was performed to determine the mass of microalgae that can be supported by the available wastewater nutrients (mainly nitrogen and phosphorous). Biomass and lipid production in the raceway ponds were simulated by using a stoichiometric aerobic bio-oxidation unit procedure. We assumed the stoichiometric balance in the cultivation follows the Redfield ratio [36]. The stoichiometry reaction was formulated in the Superpro Designer 9.0, as the following formula:

Involving nitrate $\left(\mathrm{NO}_{3}^{-}\right)$nutrient:

$$
16 \mathrm{NO}_{3}^{-}+124 \mathrm{CO}_{2}+140 \mathrm{H}_{2} \mathrm{O}+\mathrm{HPO}_{4}^{2-} \stackrel{\text { photosynthesis }}{\rightarrow} \mathrm{C}_{106} \mathrm{H}_{263} \mathrm{O}_{110} \mathrm{~N}_{16} \mathrm{P}+138 \mathrm{O}_{2}+18 \mathrm{HCO}_{3}^{-}
$$

Involving ammonia $\left(\mathrm{NH}_{4}^{+}\right)$nutrient:

$$
16 \mathrm{NH}_{4}^{+}+92 \mathrm{CO}_{2}+92 \mathrm{H}_{2} \mathrm{O}+14 \mathrm{HCO}_{3}^{-}+\mathrm{HPO}_{4}^{2-} \stackrel{\text { photosynthesis }}{\rightarrow} \mathrm{C}_{106} \mathrm{H}_{263} \mathrm{O}_{110} \mathrm{~N}_{16} \mathrm{P}+106 \mathrm{O}_{2}
$$

A whole stoichiometric balance:

$$
106 \mathrm{CO}_{2}+106 \mathrm{H}_{2} \mathrm{O}+16 \mathrm{NH}_{3}+\mathrm{H}_{3} \mathrm{PO}_{4} \stackrel{\text { photosynthesis }}{\rightarrow}\left(\mathrm{CH}_{2} \mathrm{O}\right)_{106}\left(\mathrm{NH}_{3}\right)_{16} \mathrm{H}_{3} \mathrm{PO}_{4}+106 \mathrm{O}_{2}
$$

Based on the Redfield ratio, the molecular ratio of C:N:P = 106:16:1 [37]. Meanwhile, the ratio based on the elemental weights for each component are $C: N: P=1272: 224: 31$ or equal to 41:7.2:1.0 for C, N, P, respectively. The influence of nutrient stoichiometry was shown in a previous study [30]. The initial simulation confirmed that nitrate from the investigated MWWTP is the limiting component. This means that the nitrate might be completely consumed. To achieve a similar biomass productivity as freshwater-based culture, addition of a slight amount of nitrate fertilizer to wastewater-based cultures is necessary. Substantial quantities of unconsumed DAP and $\mathrm{CO}_{2}$ will remain at the completion of the reaction. Oxygen is produced as a photosynthesis product, and salts are formed as a result of neutralization reactions between acids and bases, either soluble or insoluble.

To control the ratio of carbon, we assumed flue gases from the nearest coal fired power plant which contains approximately $15 \%$ weight of $\mathrm{CO}_{2}$ is injected to the ponds. The Haramachi Thermal Power Station $(2 \times 1000 \mathrm{MW})$ as one of the potential source of $\mathrm{CO}_{2}$ and located around two kilometers away has an average emission factor of $895.39 \mathrm{~kg}-\mathrm{CO}_{2}(\mathrm{MWh})^{-1}$ (Tohoku Electric Power Co., Ltd., Minami-soma, Japan) [38]. Based on the stoichiometric reaction formula, the average $\mathrm{CO}_{2}$ fixation rate has a ratio of approximately $1.81 \mathrm{~kg}-\mathrm{CO}_{2} \mathrm{~kg}^{-1}$-dry biomass $[39,40]$.

\subsubsection{Harvesting and Dehydration}

In the harvesting stage a concentrated biomass providing abundant bio-crude is recovered in the extraction section. Techniques for harvesting include centrifugation, flocculation, and a filter press. These techniques were selected based on effective separation of microalgae (dominant species: Desmodesmus spp. and Scenedesmus spp.). A SJ80F series disk stack centrifuge (Mitsubishi Electric, Japan) was used in the field, with an installed $12 \mathrm{~kW}$ motor and optimum operational capacity of 
$12,000 \mathrm{~L} \mathrm{~h}^{-1}$. The biomass concentration from the cultivation ponds was in the range of 0.048 to $0.063 \% \mathrm{dw}$ and the biomass slurry after centrifugation was 0.96 to $1.10 \% \mathrm{dw}$.

The flocculation method was carefully chosen to accumulate the dissolved biomass from the slurry. In the initial continuous operation, $50 \mathrm{ppm}$ of flocculant or between 10-20 g-flocculant $\mathrm{h}^{-1}$ was mixed with $250 \mathrm{~kg} \mathrm{~h}^{-1}$ of the biomass slurry. The addition of $0.5 \mathrm{~g} \mathrm{~m}^{-3}$ of the synthetic polymer flocculants (both cationic and anionic types) to the biomass slurry will increase the concentration to $300 \mathrm{~g} \mathrm{~m}^{-3}$ ( $\mathrm{pH} \mathrm{11)} \mathrm{and} \mathrm{flocculate} 95 \% \mathrm{dw}$ of biomass. Resulting flocs were characterized by a settling speed of $2.0 \mathrm{~m} \mathrm{~h}^{-1}$ and a concentration of $20 \mathrm{~kg} \mathrm{~m}^{-3}(2.0 \% \mathrm{dw})$.

The concentrated biomass from flocculation was further processed through dehydration equipment. The installed rotary vacuum drum/belt filter press has $0.93 \mathrm{~m}^{2}$ of filtration surface made from polyester nonwoven fabric canvas, producing a microalgae cake with $0.4 v / v$ porosity after drying and biomass concentration of $200 \mathrm{~kg} \mathrm{~m}^{-3}(20 \% \mathrm{dw})$. Wash water $\left(1.00 \mathrm{~L} \mathrm{~h}^{-1}\right)$ was sprayed to the screen belt to remove solids from the screen surface. In the initial comparison with other processing equipment, the belt filter press was found to utilize less energy for dehydration and able to reach $90 \%$ of biomass recovery rate. The power size of proposed dehydrator was 1.1-1.4 $\mathrm{kW}$ and average 13.8 MJ of heat per $\mathrm{kg}$ of dry matter processed were required. Average biomass filtrate flux (loading) was $250 \mathrm{~L} \mathrm{~m}^{-2} \mathrm{~h}^{-1}$ with a specific power consumption of around $1.18 \mathrm{~kW} \mathrm{~m}^{-2}$.

\subsubsection{Extraction}

HTL was identified as the best technology option and demonstrated high conversion of biomass to bio-crude and no requisite for drying and initial extraction processes for wet biomass [27,28,41,42]. For that reason, a hydrothermal liquefaction process has been introduced to produce the bio-crude from our dehydrated microalgae cake with up to $90 \%$ of moisture content [43]. Low pressure hydrothermal liquefaction equipment was utilized in our preliminary experiment for bio-crude production $\left(200-250{ }^{\circ} \mathrm{C}\right.$ and up to $\left.6.0 \mathrm{MPa}\right)$. We had simulated this equipment as a conventional stirred reactor with continuous stoichiometric reaction. The stoichiometric equations based on mass balance (weight ratio) from our experimental results were established, as two proposed formulations given below:

$$
\begin{aligned}
& 20.70 \text { Biomass }+79.30 \text { Water } \rightarrow 4.79 \text { Biocrude }+6.90 \text { Insoluble solid }+ \\
& 73.51 \text { Aqueous phase }+14.80 \text { Gas phase } \\
& \text { 19.30 Biomass }+80.70 \text { Water } \rightarrow 4.46 \text { Biocrude }+5.80 \text { Insoluble solid }+ \\
& 74.64 \text { Aqueous phase }+15.10 \text { Gas phase }
\end{aligned}
$$

As one of HTL products, the aqueous solution contains not only water, but also dissolved organic matter and solid residues. Ash as a by-product reaches up to $24.20 \%$ of total solid (TS) after filtration and drying process. Afterward, a mixture of disrupted biomass and bio-crude was sent to a decanter, where the rich oil phase was separated as a light phase and forwarded to the refinery section process. The bio-crude was produced by HTL and refined to follow ASTM D7544-09 standard specifying the physical and chemical requirements for pyrolysis liquid biofuel. These formulations further being used to estimate the reaction balance in the process simulation.

The initial experiments were conducted for three sample sizes of $50 \mathrm{~g}, 100 \mathrm{~g}$, and $320 \mathrm{~g}$ of $12.5 \%$, $20 \%$ and $80 \%$ of reactor capacity ( $500 \mathrm{~mL}$ ), respectively, to measure the energy required during the HTL process. As shown in Figure 5, the average energy consumption for $80 \%$ capacity of processing biomass was found to be approximately $4000 \mathrm{~kJ}$ or equal to $1.1 \mathrm{kWh}$ of electricity. The enthalpy difference of water was calculated to understand the heating efficiency based on its specific heat for particular temperature and pressure condition. Our initial experiments indicated that the HTL reactor has a thermal efficiency around $21 \%$, which is low. Poor thermal insulation and poor design of the heater were found to be the main reasons. The coil heater is positioned outside the reactor wall, thus the radiant heat loss is bigger than the internally transmitted heat. This reactor was designed and operated only to obtain products and understand the reaction mechanism. However, the scale-up reactor was 
designed with substantially increased energy efficiency. The initial experiments did not account for the use of energy in the heat exchanger or in other words, the efficiency of the heat exchanger system was not considered much. In this analysis, we understand that the energy quality of electricity is higher than that of the heat. To simplify, the efficiency of power generation and electricity transmission were not included in the preliminary investigation. Thus, the electricity values given here just show the final energy consumption.

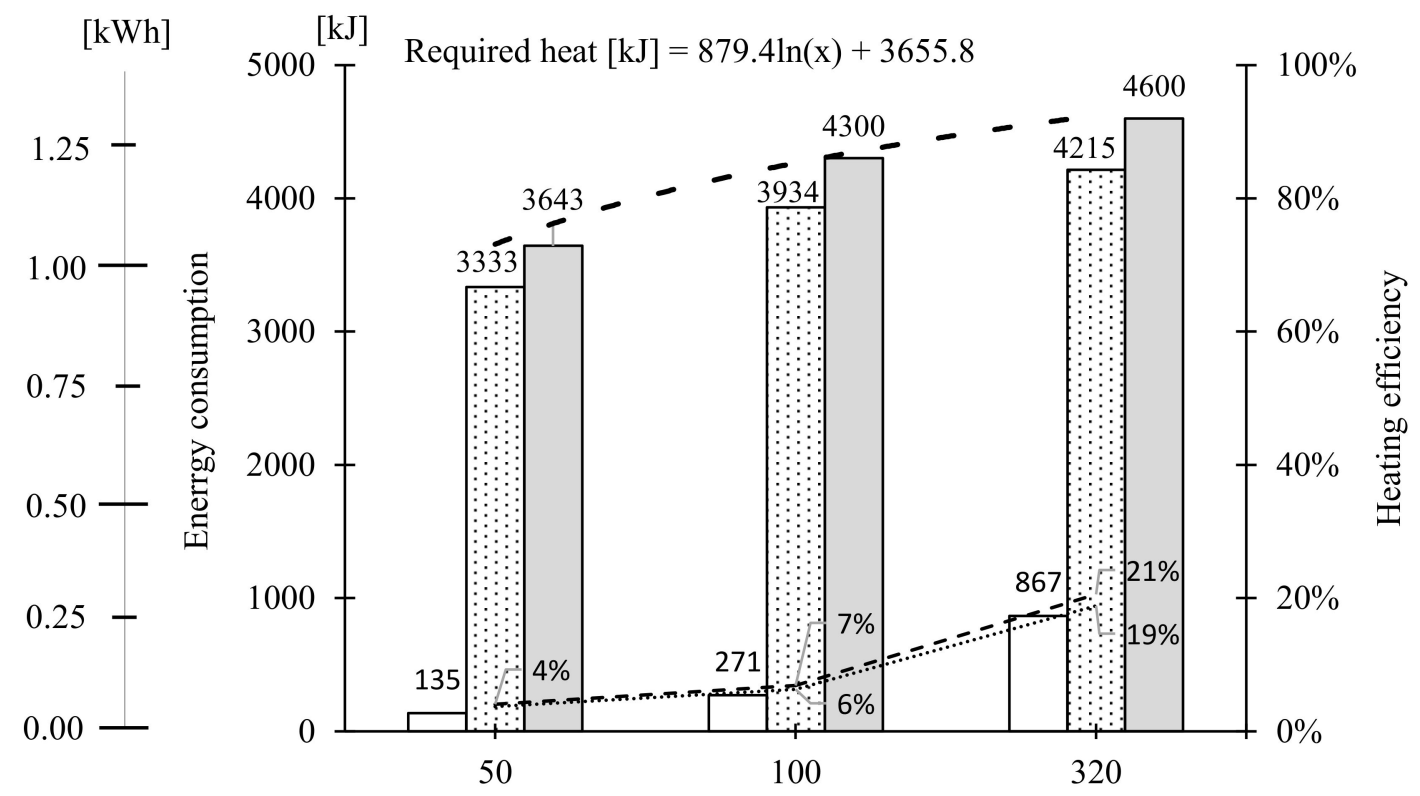

Sample amount $[\mathrm{g}]$

Figure 5. Energy consumption and heating system efficiency of low pressure hydrothermal decomposition.

\section{Results and Discussion}

\subsection{Microalgae Biomass Productivity}

The process design of 1 ha cultivation that was based on our preliminary field experiment, determined the quantity of microalgae biomass that can be produced. The climate conditions in Fukushima fluctuate a lot during the year, resulting in a varied biomass production. When provided an adequate, stable and continuous supply of nutrients and enough sun radiation, we found that the native algae in Fukushima can adapt and grow well in cold environments, although the average temperature in winter is about $5{ }^{\circ} \mathrm{C}$, which normally means the temperature might be below the freezing point of water during night.

Figure 6 shows the annual biomass productivity, which was the lowest during the winter season (December 2014-January 2015) and the highest ran from the spring to autumn season. The first $Y$ axis shows the estimated annual tonnage productivity, meanwhile the second $Y$ axis shows the estimated daily productivity per area square. The average annual lipid productivity shows almost the same ratio, with an estimated value of $10 \%$ of the biomass productivity in every month. Early results from the field measurements and laboratory analysis show that the native microalgae in Fukushima were grown mixotrophically and had as much as $10.0 \pm 3.5 \%$ of lipid content per dry weight. Initial investigations showed that wastewater microalgae were naturally low in lipid content. Hence, increased biomass production is required to raise the total lipid yield. The lipid fraction would show different values during the year as the climate conditions are changeable and they represent stress conditions that affect the amount of lipids stored by microalgae [44]. More thorough reports about this condition are in preparation for an upcoming journal publication. 


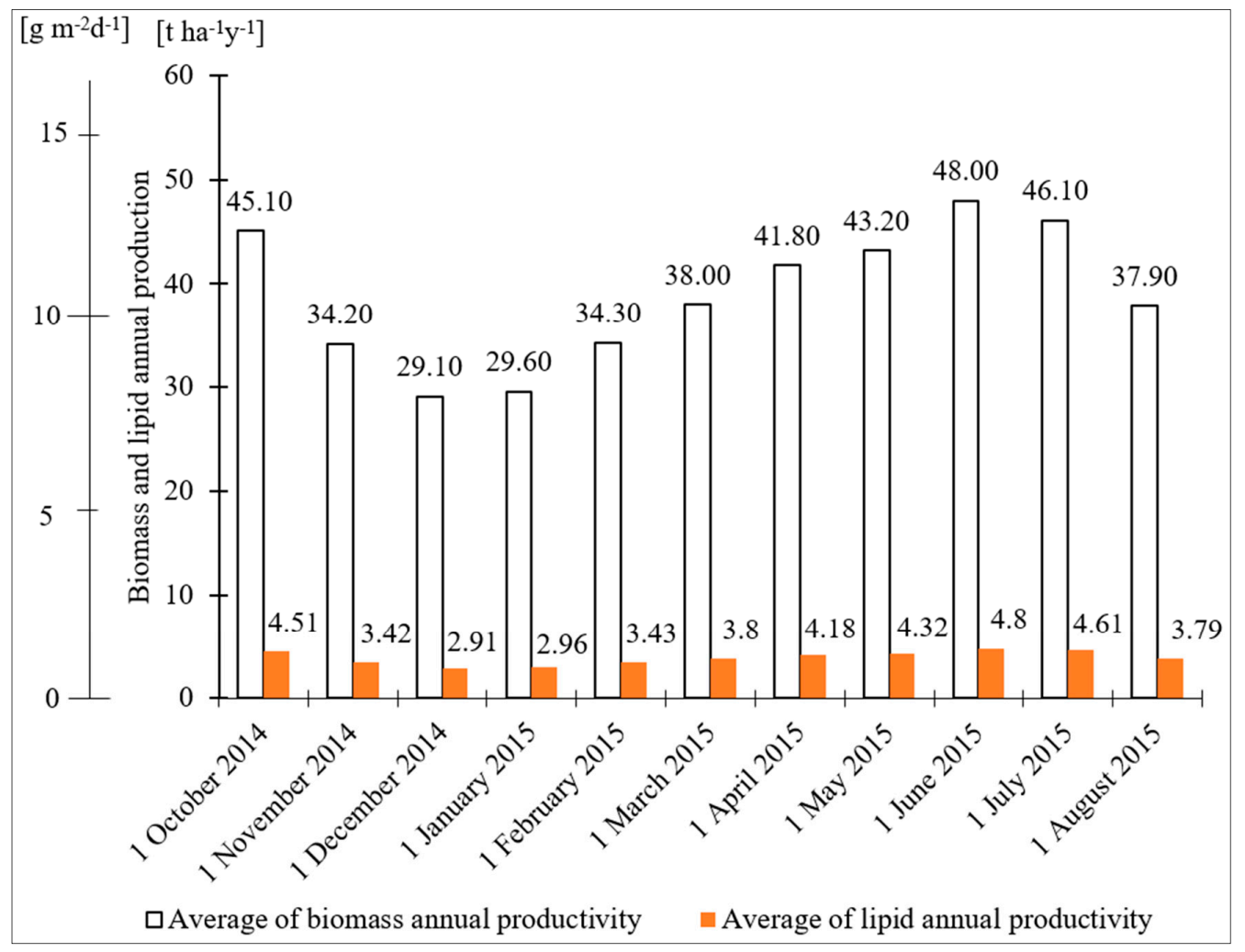

Figure 6. Annual biomass and lipid productivities in the raceway ponds with water depth about $0.3 \mathrm{~m}$, HRT 4 days and sodium acetate addition.

The average biomass productivity achieved was between 8.5 and $14 \mathrm{~g} \mathrm{~m}^{-2} \mathrm{~d}^{-1}$ at most. However, from our ongoing field experiments, it is possible to achieve productivity $17.3 \mathrm{~g} \mathrm{~m}^{-2} \mathrm{~d}^{-1}$ in $0.3 \mathrm{~m}$ depth throughout a year and based on these values, the dry weight of annual biomass productivity might reach up to 60.55 tons $\mathrm{ha}^{-1} \mathrm{y}^{-1}$ for 350 days of annual running operation [29]. These numbers are confirmed by the empirical estimation of some previous reports regarding the current upper limit of long-term commercial productivity [45]. Lower culture depth and addition of nutrients cause increased production costs, however, our preliminary findings from ongoing experiments showed that the productivity might be higher by culture and process optimization. Based on our early data as shown in Figures 3, 4 and 6, it is too early to establish an equation to relate these weather factors to the final algal biomass productivity. The governing equations are a complex formula which could not only include the climate conditions, but also nutrient availability, type of species and so on. Thus, we did not include the equations that we found in the initial stage of analysis. We are preparing another manuscript to specifically discuss this issue.

\subsection{Integrated Process Plant System}

The proposed integrated cultivation with effluent from municipal wastewater treatment was effectively assessed in this study. A primarily treated municipal wastewater served as a nutrient source for microalgae growth, while the microalgae biomass served as a bio-treatment for removing nitrogen and phosphorus.

In our early experiments no heat treatment was applied to the cultivation ponds during the winter. Thus, the native microalgae strains were cultivated under their original climate conditions. Our installed paddlewheel motor run with $309 \mathrm{kWh} \mathrm{d}^{-1}$ of electricity to maintain the flow rate between $0.15-0.30 \mathrm{~m} \mathrm{~s}^{-1}$, which corresponded to a previous study [46]. The total water supply is between 
$166.7-333.3 \mathrm{~m}^{3} \mathrm{~h}^{-1}$ for either freshwater and treated municipal wastewater or 200,040-399,960 $\mathrm{m}^{3} \mathrm{y}^{-1}$ without water recycling.

Figure 7 shows a proposed integrated process system of microalgae biomass to bio-crude modified from the Fukushima existing facility with water and nutrient recycling. The field experiment and process simulation results revealed that operating conditions such as retention time, temperature, pressure, moisture and solid content of the microalgae slurry have a significant influence in the upstream to downstream processes.

The main stages included in the proposed pathways of microalgae biomass to be processed as bio-oil, starting from culture, harvesting-dehydration (disk stack centrifuge and vacuum drum filter press) and extraction (hydrothermal liquefaction and hexane extraction). The designated processes were based on the particular equipment installed in Minami-soma city in Fukushima prefecture. The detail specifications of each component are listed in this study.

Table 3 shows the equipment specification for each stage in the integrated process plant design simulated for 1 ha of cultivation open pond (1000 $\mathrm{m}^{2} \times 10$ ponds) possible to produce biomass approximately $5.7-7.5 \mathrm{~kg} \mathrm{~h}^{-1}(0.048-0.063 \% \mathrm{dw})$. Total circulated water was about $12 \mathrm{~m}^{3} \mathrm{~h}^{-1}$.

Table 3. Process equipment and parameters for each step of process.

\begin{tabular}{|c|c|c|c|c|c|c|}
\hline Unit & $\begin{array}{l}\text { Installation } \\
\text { Price } \\
\text { [JPY] }\end{array}$ & $\begin{array}{l}\text { Pressure } \\
\text { Design } \\
\text { [MPa] }\end{array}$ & $\begin{array}{c}\text { Temp } \\
\text { Design } \\
{\left[{ }^{\circ} \mathrm{C}\right]}\end{array}$ & $\begin{array}{c}\text { Power } \\
\text { Requirement } \\
{[\mathrm{kW}]}\end{array}$ & $\begin{array}{c}\text { Estimated } \\
\text { Volume Rate }\end{array}$ & $\begin{array}{c}\text { Estimated Biomass } \\
\text { Produced } \\
{\left[\mathrm{kg} \mathrm{h}^{-1}\right]}\end{array}$ \\
\hline $\begin{array}{l}\text { Pump system in } \\
\text { (centrifugal pump) }\end{array}$ & $2,078,000$ & 0.35 & 25 & 1.53 & $12.00 \mathrm{~m}^{3} \mathrm{~h}^{-1}$ & - \\
\hline $\begin{array}{c}\text { ORP- } \\
\text { Paddlewheel system }\end{array}$ & $8,474,400$ & 0.10 & 25 & 51.56 & $\begin{array}{l}300.00 \mathrm{~m}^{3} \times 10 \\
\text { unit }\end{array}$ & $5.7-7.5$ \\
\hline $\begin{array}{l}\text { Delivery pump } \\
\text { system } \\
\text { (centrifugal pump) }\end{array}$ & $2,140,000$ & 0.35 & 25 & 1.64 & $12.00 \mathrm{~m}^{3} \mathrm{~h}^{-1}$ & $5.7-7.5$ \\
\hline $\begin{array}{l}\text { Centrifugation } \\
\text { (disk stack) }\end{array}$ & $20,000,000$ & 0.10 & 27 & 12.00 & $11.95 \mathrm{~m}^{3} \mathrm{~h}^{-1}$ & $5.6-7.4$ \\
\hline $\begin{array}{l}\text { Slurry pump system } \\
\text { (centrifugal pump) }\end{array}$ & 867,000 & 0.35 & 25 & 0.03 & $0.25 \mathrm{~m}^{3} \mathrm{~h}^{-1}$ & $5.6-7.4$ \\
\hline $\begin{array}{c}\text { Dehydration } \\
\text { (Belt filter press) }\end{array}$ & $6,000,000$ & 0.08 & 25 & 1.10 & $0.93 \mathrm{~m}^{2}$ & $5.1-7.1$ \\
\hline $\begin{array}{l}\text { Low pressure } \\
\text { HTL reactor }\end{array}$ & $40,000,000$ & 20.00 & 250 & 16.58 & $\begin{array}{c}23.00 \mathrm{~L} \\
\text { (estimated size) }\end{array}$ & $\begin{array}{l}0.51-0.67 \mathrm{~L} \mathrm{~h}^{-1} \\
\text { (bio-crude) }\end{array}$ \\
\hline
\end{tabular}

Treatment of supernatant from the harvesting and dehydration stages is necessary since our target is to reuse the water for microalgae culture. Another issue is that the supernatant has a high concentration of dissolved organic matter and minerals, which caused salt build-up of more than $1.86 \mathrm{~kg} \mathrm{~h}^{-1}$. Thus, additional equipment such as a sedimentation pond must be installed, to decrease the salt concentration from recycling water and supernatant. 


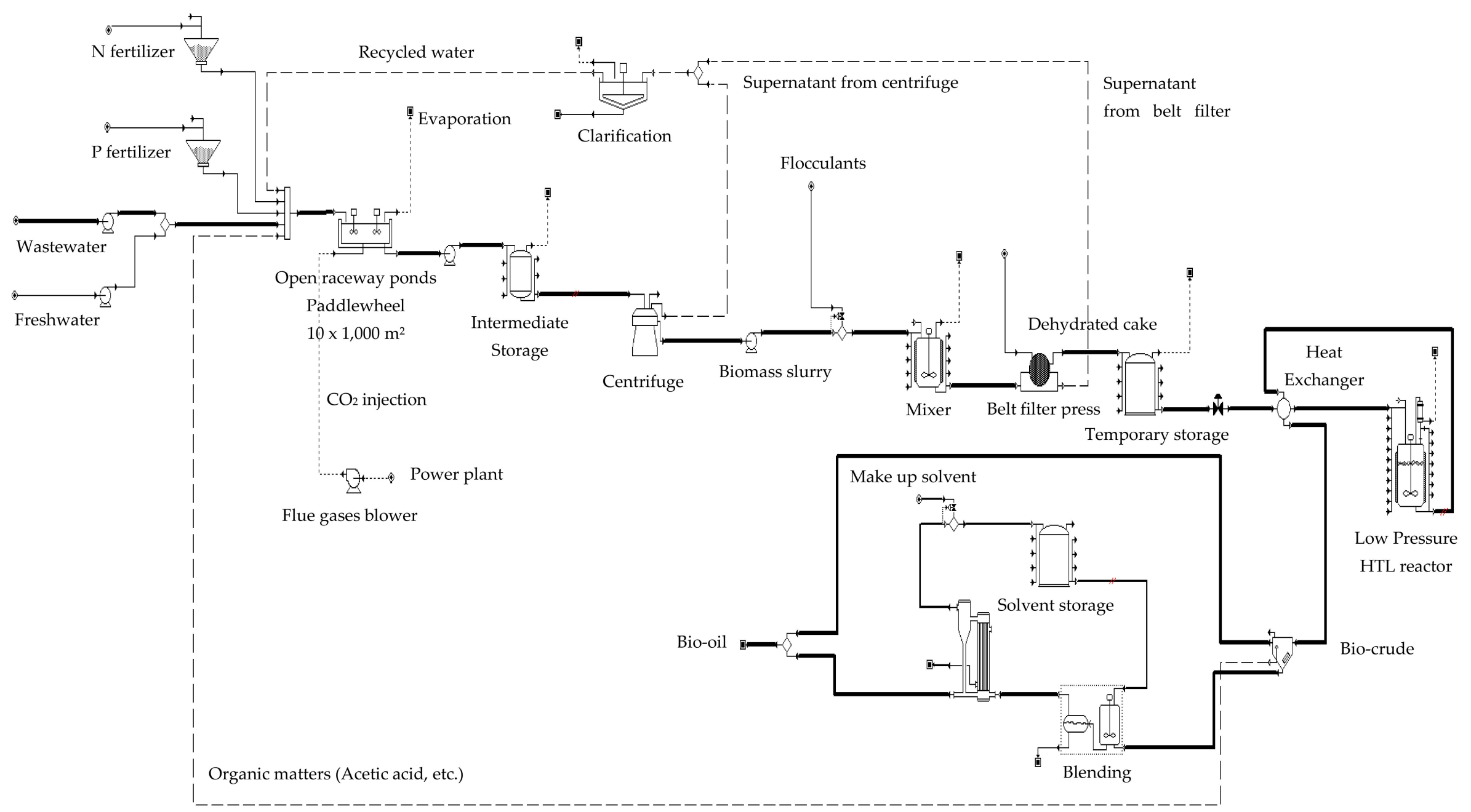

Figure 7. Process plant design for 1 ha cultivation pond by using treated water from the primary MWWTP using Superpro Designer. 
Gravity-based sedimentation is preferred since it offers the lowest energy penalty, easy operation and maintenance. This technique used the Stokes' law principle and reduced the total soluble solid (TSS) contents to approximately $1-5 \%$. Based on the calculation, the surface size of clarification pond will cover $8.74 \mathrm{~m}^{2}$ with $1.5 \mathrm{~m}$ depth. A $0.6 \mathrm{~kW}$ motor size pump is required for water circulation. Particulate concentration in the sludge was $0.3 \mathrm{~g} \mathrm{~L}^{-1}$ with a liquid viscosity of $1.0 \mathrm{mPa} \cdot \mathrm{s}$. The drawback with sedimentation lies however in the small size of particles, resulting in a slow settling rate $[18,47]$.

The harvesting efficiency of the rapid centrifugation separation method was found to be very high, from 92 to $95 \%$ biomass recovery. A $750 \mathrm{~W}$ recirculation pump with a $15 \mathrm{~m}^{3} \mathrm{~h}^{-1}$ flow rate was installed in the field. The biomass slurry flow rate was $11.95 \mathrm{~m}^{3} \mathrm{~h}^{-1}$ with a solid concentration of $0.05 \% \mathrm{dw}$. Centrifugation is expensive and energy intensive, but on the other hand, it is a very effective technique to harvest microalgae. In some recent studies average centrifugation system power inputs between $0.9-8.0 \mathrm{kWh} \mathrm{m}^{-3}[18,48]$, or approximately $3.0 \mathrm{kWh} \mathrm{kg}^{-1}$ of biomass [17] were reported. Our preliminary investigation showed that the average electricity needed for each $\mathrm{kg}$ of separated biomass product was $2.11 \mathrm{kWh} \mathrm{kg}^{-1}$ biomass, and $1.00 \mathrm{kWh} \mathrm{m}^{-3}$ slurry which is more efficient than the mentioned references. However, we also found that the energy efficiency for centrifugation may also depend on the particular characteristics of the microalgae. The negatively charged surfaces of the microalgae prevent these organisms from easily settling by gravity [19]. We found that in the harvesting stage, the surface of microalgae cells is usually negatively charged, preventing them from sticking together in the broth. Thus, flocculants were added during harvesting to solve this problem. The flocculation technique was necessary to assist the harvesting stage by aggregating the microalgae and increasing the particle size [19]. The requirement of polyaluminum chloride (PAC) mixed with the concentrated biomass slurry before sent to the belt filter press for biomass cake production was estimated at about $12.52 \mathrm{~g} \mathrm{~h}^{-1}$. Our initial analysis estimated the operational cost at approximately $165 \mathrm{JPY} \mathrm{kg}^{-1}$ flocculants to produce $5.6-7.4 \mathrm{~kg}_{\text {biomass }} \mathrm{h}^{-1}$.

Based on our calorific value measurement, an average high heating value (HHV) of $38.2 \mathrm{MJ} \mathrm{L}^{-1}$ was obtained from the bio-oil extracted in the downstream process. The yield of bio-oil and its chemical properties varied greatly. Bio-oil yields ( $24-51 \%$ of final products) and physicochemical characteristics were highly influenced by the conversion process and strain selection. In 350 days of annual operation, in average $4284-5628 \mathrm{~L}$ of bio-crude can be produced. Thermal recovery by utilizing a heat exchanger allows reducing the energy consumption during lipid extraction. A preheating step was designed as an energy recovery technique for the dehydrated cake before HTL processing. At least $14.64 \mathrm{~kJ} \mathrm{~s}^{-1}$ of heat could be recovered. Without optimization, low pressure hydrothermal decomposition of microalgae was not likely to be the best route in the proposed pilot-phase of the technology, however significant research and development effort are necessary. Another of our ongoing experiments is by using a continuous HTL system of plug flow reactor which is very promising to increase the HTL oil yield up to $60 \%$ as also confirmed in other reports $[27,28]$. This system was reported to have a low energy requirement of around $0.211 \mathrm{kWh} \mathrm{L}^{-1}$ bio-oil product in a continuous operation by an energy efficiency improvement. The bio-crude further can be purified by using a unique upgrading process. There are several methods to upgrade HTL products [49]. One of these methods is the separation which was the conventional way to isolate high-value products or facilitate further processing to produce fuel and high-value products. Removal of water content in the oil fraction was specifically important for upgrading processes, as water may cause catalyst inactivity. The separation method consists of two techniques, solvent extraction, and distillation. Other possible techniques are hydrogenation, catalytic cracking, esterification and hybrid processes.

\subsection{Material and Energy Balance}

As shown in Figure 8, the material balance was calculated based on a dry weight for each processes. A proposed continuous process of microalgae biomass to bio-crude is based on field data from Fukushima, with water and nutrient recycling of the supernatant from the dehydration processes 
(centrifugation, flocculation and belt filter press). Closed loop water recycling in this plant can lower the energy penalty and freshwater requirement and also increase the nutrient recovery.

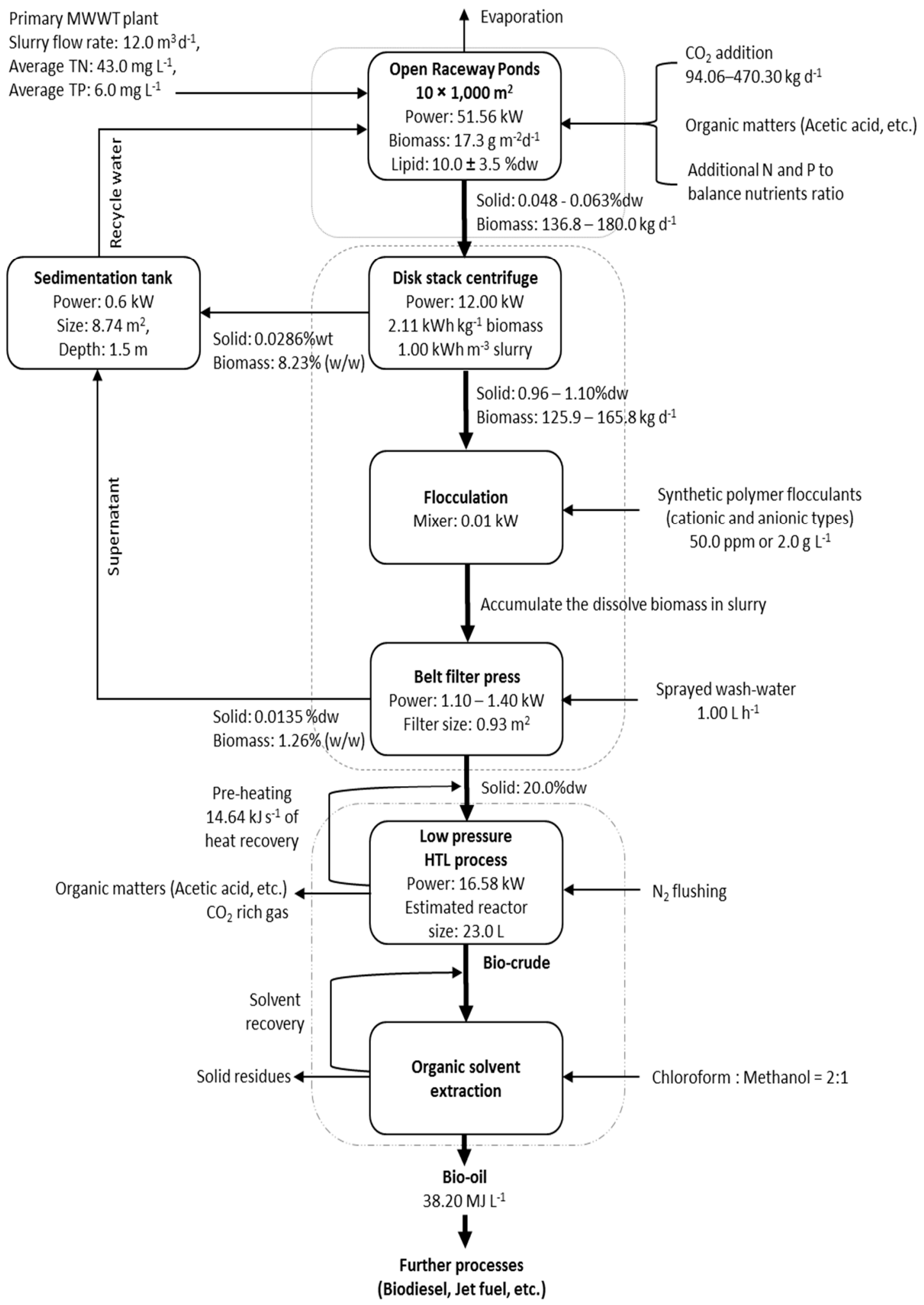

Figure 8. Integrated process diagram of microalgae culture to bio-crude and bio-oil products based on the simulation. 
The simulation result confirmed that at least $89.63 \mathrm{~kW}$ of installed power is required to run 1 ha of total cultivation ponds and all processing facilities with approximately $752 \mathrm{GWh} \mathrm{y}^{-1}$ of power demand, annually. Figure 9 shows the distribution of power demand in kW. Based on the results, the highest power demand came from the paddle wheel and HTL which are required for circulating water in the ponds and the extraction-conversion processes, respectively.

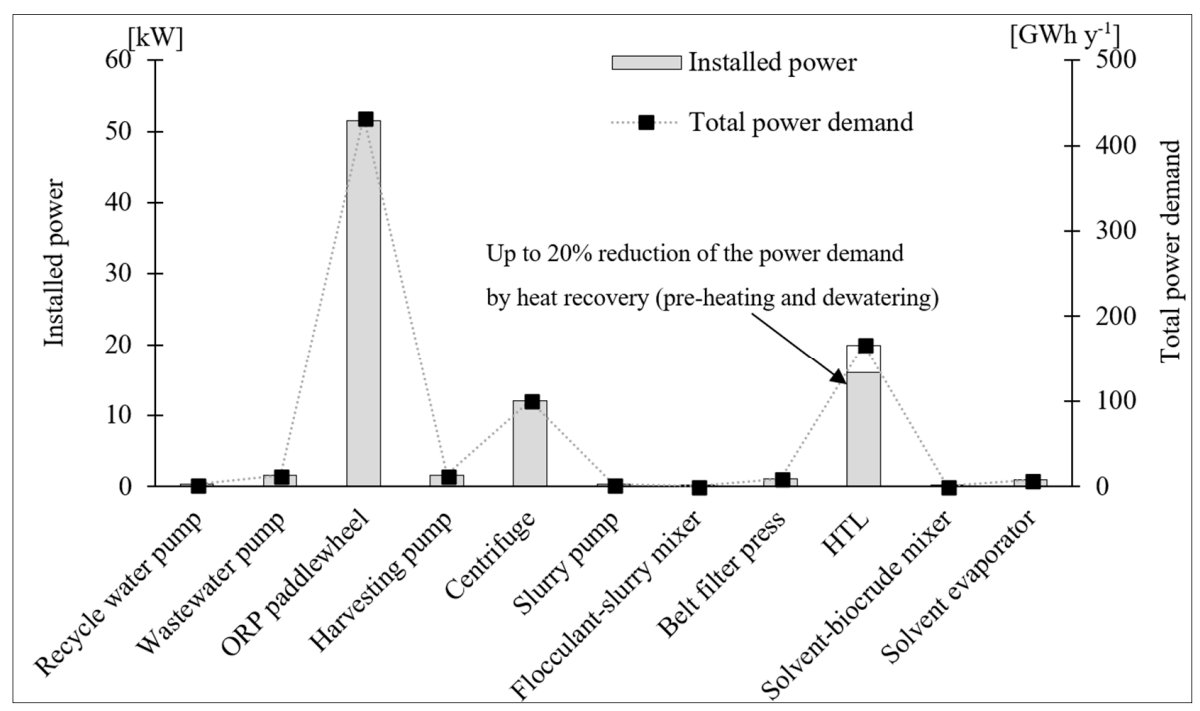

Figure 9. Power demand distribution for a 1 ha cultivation area.

Figure 10 shows the monthly energy input in a year of cultivation. The highest energy input occurred during the winter period. Meanwhile, the lowest occurred throughout the summer season.

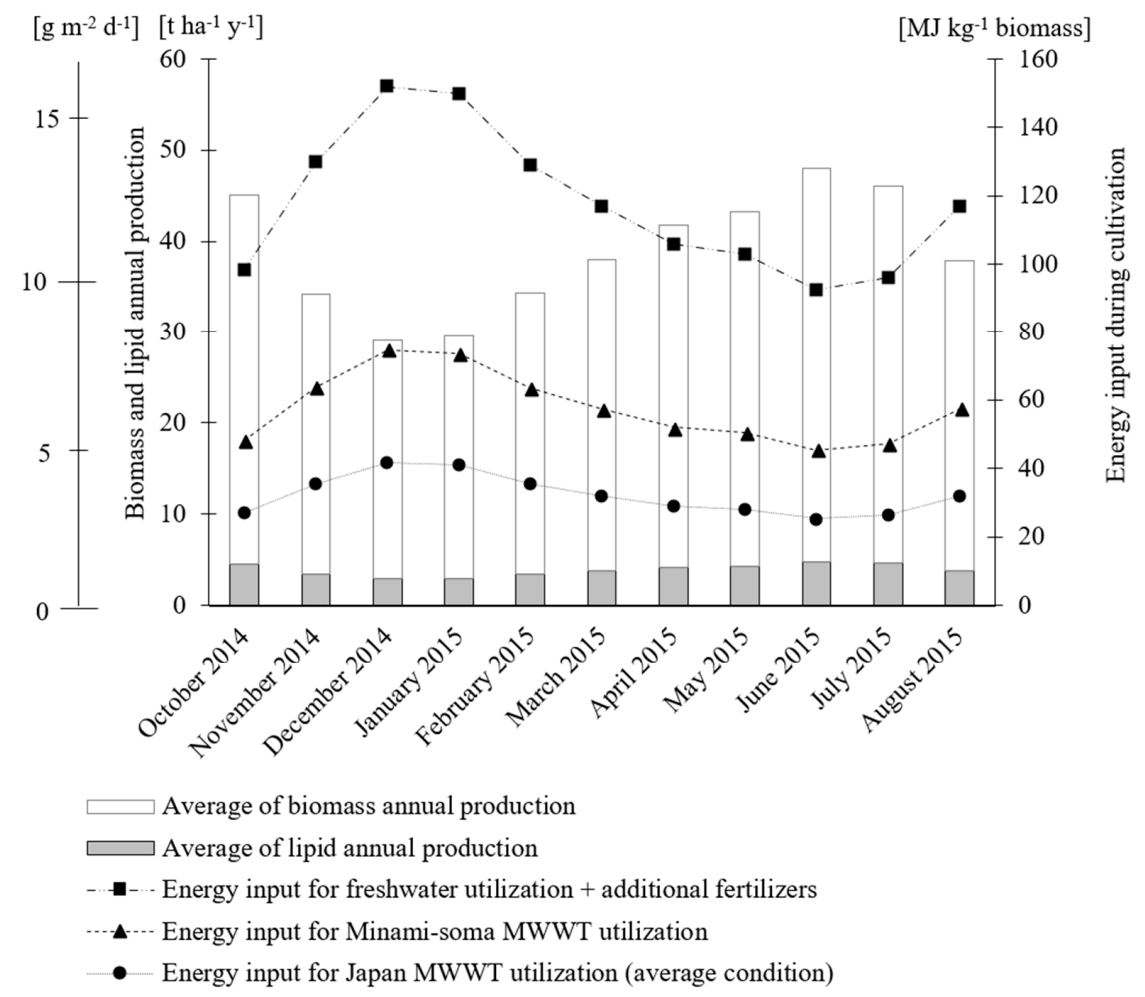

Figure 10. Total energy input during cultivation stage. 
Water and nutrient utilization from the primary municipal wastewater treatment gave an additional benefit to lowering the energy input compared with the usage of ground or filtered water. The difference reached up to 3.5 times the total energy input which gave a strong positive energy balance. The type of input energy that possible to be avoided primarily from clean water processing and embedded energy from commercial nutrient utilization. Water, free nutrient sources, and electricity play a significant role in this process as a consequence of the large scale facility.

The integrated production system by utilizing primarily treated municipal wastewater helps to reduce the total cost during cultivation stage up to $75 \%$ by energy efficiency and optimum nutrient utilization. The need for nitrogen and carbon source fertilizer (medium $\mathrm{K}$ and sodium acetate) for growth enhancement of the microalgae also can be reduced by utilizing flue gases from the nearest power plant and organic matter from hydrothermal processing co-products $[50,51]$. Our experiments indicated that the aqueous phase obtained after HTL has a high content of organic nutrients such as $\mathrm{PO}_{4}^{3-}, \mathrm{NH}_{4}^{+}, \mathrm{CH}_{3} \mathrm{COO}^{-}$, besides metallic cations like $\mathrm{K}^{+}, \mathrm{Na}^{+}$or $\mathrm{Mg}^{2+}$ which can be used as additional organic nutrients to the culture.

\subsection{GHG Emission from Cultivation Stage}

Potential GHG emissions were calculated based on the process simulation of the complete material and energy balance of the proposed system. The inputs for $\mathrm{CO}_{2}$ eq footprint calculation included all of the fertilizers and electricity used per month. As shown in Figure 11, the utilization of the municipal wastewater successfully reduces the GHG emission during cultivation. Our initial assessment found that the $\mathrm{CO}_{2}$ eq footprint of a microalgae bio-oil production system for Minami-soma primary MWWTP utilization is slightly higher compared with utilization of Japan average MWWTP. This is mainly due to the low biomass and lipid productivity and also available free nutrients ( $\mathrm{N}$ and $\mathrm{P})$, which mean considerable amounts of synthetic fertilizers are required to balance the nutrient ratio in the culture.

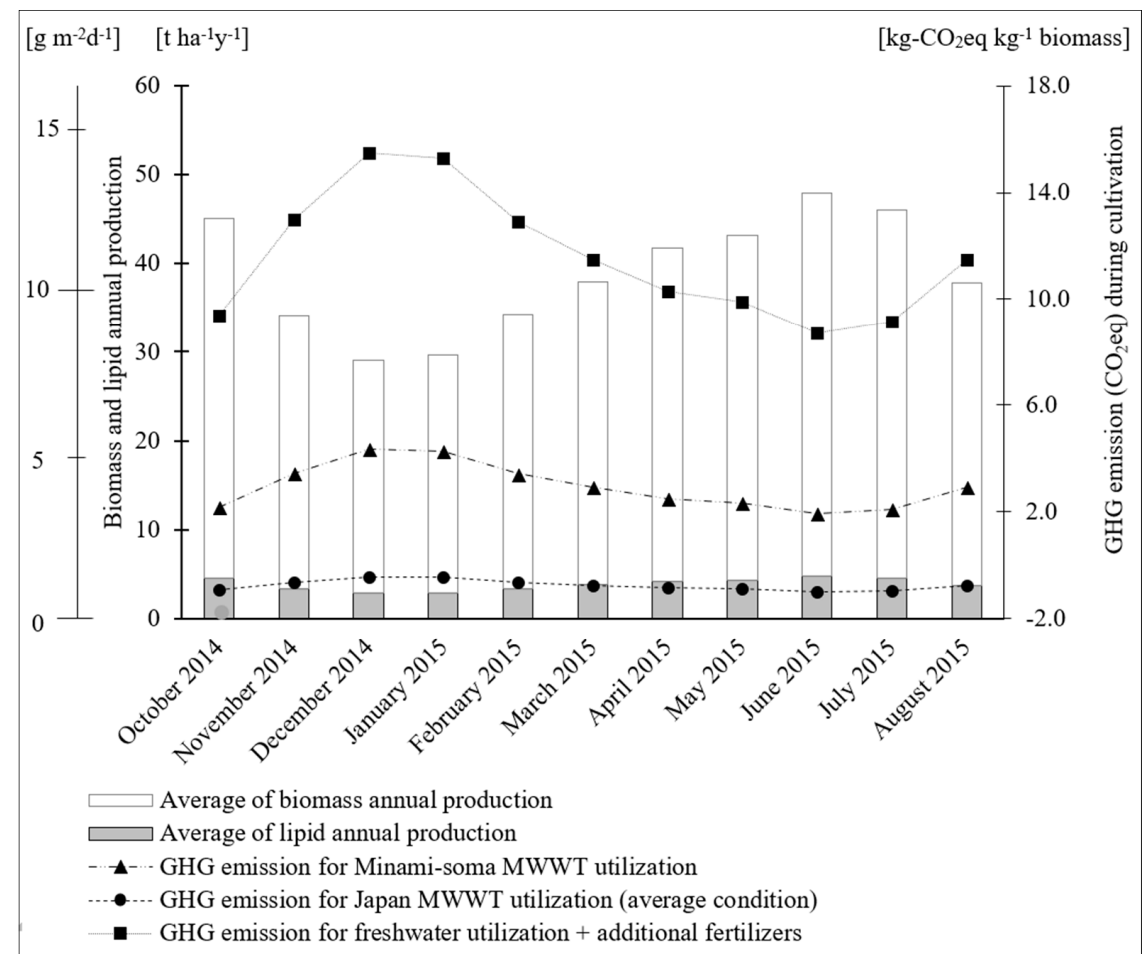

Figure 11. Total $\mathrm{CO}_{2}$ eq footprint during cultivation. 
The $\mathrm{CO}_{2}$ eq footprint also considered the injection of flue gases produced at the nearest power plant into the cultures. The partial $\mathrm{CO}_{2}$ pressure in the air is not sufficient $(0.032 \mathrm{kPa})$ to achieve high growth rates since the optimal value is $0.1 \mathrm{kPa}[39,52] . \mathrm{CO}_{2}$ was pressurized and injected to the pond through PVC pipes. $\mathrm{CO}_{2}$ injection system required electricity about $3.51 \mathrm{Wh} \mathrm{kg}^{-1}$ of flue gases. However, our preliminary research indicated that $\mathrm{CO}_{2}$ utilization rate of microalgae (Chlorella) is less than $10.0 \%$ in the case of injection of flue gas from the coal-fired power station to the open ponds. Since the open ponds have high losses due to direct exposure to the atmosphere, extra $\mathrm{CO}_{2}$ needs to be injected by carefully maintain the appropriate $\mathrm{pH}$ of the culture. The excess $\mathrm{CO}_{2}$ was lost to the air together with evaporation stream leaving the raceway ponds. This stream also contained nitrogen, oxygen, a small amount of $\mathrm{NO}_{\mathrm{x}}$ and a considerable amount of water vapor $\left(236.10 \mathrm{~kg} \mathrm{~h}^{-1}\right)$. Some combustion products such as $\mathrm{NO}_{\mathrm{x}}$ are also effective when used as an additional nutrient for microalgae [53]. Overall, approximately $9.45 \mathrm{up}$ to $16.05 \mathrm{~kg}_{-}-\mathrm{CO}_{2} \mathrm{~h}^{-1}$ is required to balance the nutrients ratio for total 1 ha cultures, and $\mathrm{CO}_{2}$ should be fed continually during daylight hours. Based on our calculations, the average $\mathrm{CO}_{2}$ emission from the wastewater treatment in Japan is $0.26 \mathrm{~kg}-\mathrm{CO}_{2}$ per m processing wastewater. Kasima MWWTP receives $877 \mathrm{~m}^{3} \mathrm{~d}^{-1}$ of wastewater from the residential area and potentially release approximately $228.02 \mathrm{~kg}-\mathrm{CO}_{2} \mathrm{~d}^{-1}$ or 83.3 tons- $\mathrm{CO}_{2} \mathrm{y}^{-1}$ from its annual operation. Further based on our analysis, producing $1 \mathrm{~kg}$ of microalgae biomass will potentially reduce $0.55 \mathrm{~kg}-\mathrm{CO}_{2}$ emissions per $\mathrm{m}^{3}$ of treated wastewater which matches other experimental results [54].

In the early simulation stage, we did not include the influence of plant construction in our analysis of GHG emissions. We mainly focused on the potential GHG emission reduction from the nutrient substitution in wastewater cultivation. We will continue to study how GHG emissions are affected by not only direct use of energy and materials, but also indirect uses like the construction of each piece of equipment, operation, utilities, etc.

\subsection{Economic Evaluation}

Economic and sensitivity analyses were conducted for this study to estimate a range of costs for bio-oil production. The electricity cost estimation is based on the current average price of electricity in Japan, about $25 \mathrm{JPY} \mathrm{kWh}^{-1}$. Figure 12 shows the production cost disbursement for each stage-process. 


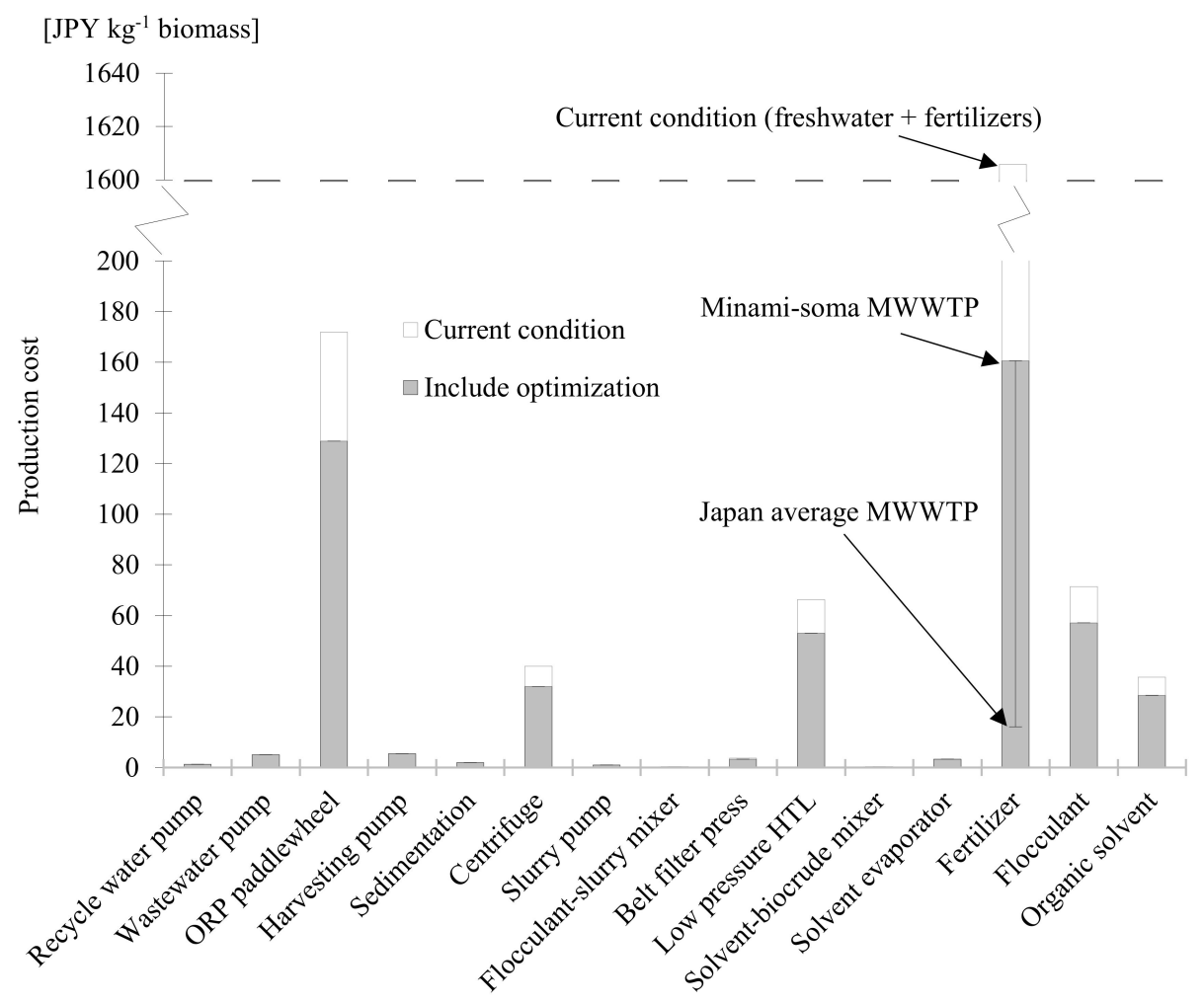

Figure 12. Production cost for each stage processes based on the optimized process simulation.

Utilization of wastewater as the medium for cultivation potentially cut the nutrients cost from 1605.9 JPY kg-1 biomass to $160.6 \mathrm{JPY} \mathrm{kg} \mathrm{g}^{-1}$ biomass. This includes the operational cost savings from the primary municipal wastewater treatment. The cost can vary during the year due to seasonal production, whereby in the winter the biomass production can drop dramatically from $0.5 \mathrm{~g} \mathrm{~L}^{-1}$ down to $0.1 \mathrm{~g} \mathrm{~L}^{-1}$. There are still some opportunities to reduce the total production costs further by finding the most efficient technique for water recirculation to the cultures, a cheaper harvesting and dehydration technique, and also efficient thermal and chemical treatment for bio-oil extraction [49-57]. As shown in Figure 12, the sensitivity analysis also includes a variable for the electricity consumed and pre-heating as efficient thermal utilization in the HTL process. The estimated cost of biomass production in Minami-soma after optimization for cultivation to dehydration is approximately $397.2 \mathrm{JPY} \mathrm{kg}^{-1}$.

Most of the assumptions were made based on the Japanese economic conditions in 2016. Bank of Japan interest rate $(-0.1 \%)$ and a project life time was 20 years with infrequent maintenance were assumed. Production capacity is estimated $90 \%$ for 350 days operation and 15 days off for annual cleaning and maintenance. Sensitivity analysis has been conducted based on biomass productivity. Figure 13 shows that the cost reduction could reach down to $100 \mathrm{JPY} \mathrm{L} \mathrm{L}^{-1}$ for $50 \mathrm{~g} \mathrm{~m}^{-2} \mathrm{~d}^{-1}$ of biomass productivity with $50 \%$ of lipid yield percentage of dry weight. The production cost was roughly based on our estimation of total equipment costs and included the operational expenditure from freshwater, fertilizers, electricity, required flocculant and organic solvent based on 1 ha cultivation system in Minami-soma, Fukushima. 


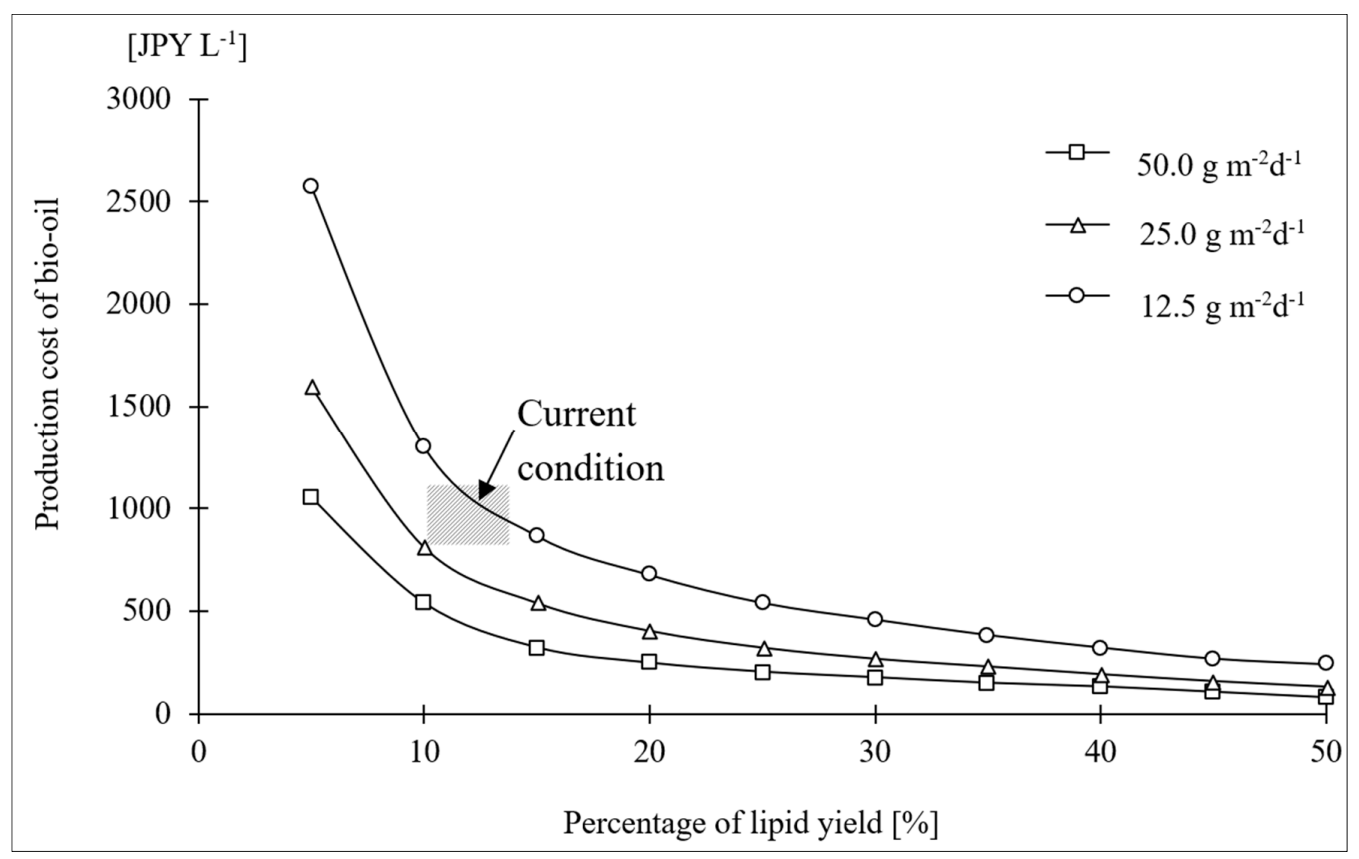

Figure 13. Sensitivity analysis of bio-oil cost reduction based on potential biomass productivity and lipid fractions.

\section{Conclusions}

This study highlights native microalgae polyculture and its potential using nutrients from primary municipal wastewater treatment and $\mathrm{CO}_{2}$ from flue gases. The proposed integrated process system for microalgae growth reduces the energy input and GHG emissions. A combination of the processes diminishes excess utilization of fertilizers and freshwater, further decreasing the total production costs. The biggest challenges of the proposed system to become viable are the unexpected presence of contaminants and suspended solids (SS) build up in wastewater that may have some negative impact on the long run and continuous operation of the microalgae culture, and also affect the quality of the biomass products. In this study, the annual weather conditions in the temperate region in Japan also presents some handicaps to keep the biomass productivity stable for a large scale cultivation system. Maintaining a continuous nutrient flow and its suitable composition also represent major bottlenecks for the microalgae system to be feasible and commercialized. However, based on the actual pilot plant studies, our promising results should effectively contribute to promote the future dissemination of microalgae biofuel systems in Japan.

Author Contributions: Conceptualization, Writing-Review \& Editing, Supervision Project Administration, and Funding Acquisition, R.N., M.N. and M.M.W.; Validation and Resources, J.I., M.D. and S.I.; Methodology, Software, Formal Analysis, Investigation, Resources, Data Curation, Writing-Original Draft Preparation, and Visualization, N.A.S.

Funding: This research was funded by the Indonesia scholarship program for research and innovation in science and technologies (RISET-PRO) World Bank Loan No. 8245-ID and a grant from Next-generation renewable energy development program for Fukushima reconstruction and revitalization, Fukushima Prefecture, Japan.

Acknowledgments: This work was supported by the Indonesia scholarship program for research and innovation in science and technologies (RISET-PRO) World Bank Loan No. 8245-ID and a grant from Next-generation renewable energy development program for Fukushima reconstruction and revitalization, Fukushima Prefecture, Japan.

Conflicts of Interest: The authors declare no conflict of interest. 


\section{References}

1. Juneja, A.; Ceballos, R.M.; Murthy, G.S. Effects of Environmental Factors and Nutrient Availability on the Biochemical Composition of Algae for Biofuels Production: A Review. Energies 2013, 6, 4607-4638. [CrossRef]

2. Davis, R.; Markham, J.; Kinchin, C.; Grundl, N.; Tan, E.C.D. Process Design and Economics for the Production of Algal Biomass: Algal Biomass Production in Open Pond Systems and Processing through Dewatering for Downstream Conversion; National Renewable Energy Laboratory: Golden, CO, USA, 2016. Available online: http:/ /www.nrel.gov/docs/ fy16osti/64772.pdf (accessed on 1 March 2016).

3. Sasongko, N.A.; Noguchi, R.; Ahamed, T. Environmental load assessment for an integrated design of microalgae system of palm oil mill in Indonesia. Energy 2018. [CrossRef]

4. Sasongko, N.A.; Noguchi, R.; Ahamed, T.; Takaigawa, T. Introduction of Integrated Energy Plantation Model for Microalgae-Using Palm Oil Mill Effluent (POME). J. Jpn. Inst. Energy 2015, 94, 561-570. [CrossRef]

5. Devi, M.P.; Subhash, G.V.; Mohan, S.V. Heterotrophic cultivation of mixed microalgae for lipid accumulation and wastewater treatment during sequential growth and starvation phases: Effect of nutrient supplementation. Renew. Energy 2012, 43, 276-283. [CrossRef]

6. Ebrahimian, A.; Kariminia, H.-R.; Vosoughi, M. Lipid production in mixotrophic cultivation of Chlorella vulgaris in a mixture of primary and secondary municipal wastewater. Renew. Energy 2014, 71, 502-508. [CrossRef]

7. Lam, M.K.; Yusoff, M.I.; Uemura, Y.; Lim, J.W.; Khoo, C.G.; Lee, K.T.; Ong, H.C. Cultivation of Chlorella vulgaris using nutrients source from domestic wastewater for biodiesel production: Growth condition and kinetic studies. Renew. Energy 2017, 103, 197-207. [CrossRef]

8. Craggs, R.J.; Lundquist, T.; Benemann, J. Wastewater Treatment Pond Algal Production for Biofuel. Sci. Algal Fuels 2012, 425-445. [CrossRef]

9. Craggs, R.J.; Sutherland, D.; Campbell, H. Hectare-scale demonstration of high rate algal ponds for enhanced wastewater treatment and biofuel production. J. Appl. Phycol. 2012, 24, 329-337. [CrossRef]

10. Sutherland, D.L.; Howard-Williams, C.; Turnbull, M.H.; Broady, P.A.; Craggs, R.J. Enhancing microalgal photosynthesis and productivity in wastewater treatment high rate algal ponds for biofuel production. Bioresour. Technol. 2015, 184, 222-229. [CrossRef] [PubMed]

11. Mehrabadi, A.; Craggs, R.J.; Farid, M.M. Wastewater treatment high rate algal ponds (WWT HRAP) for low-cost biofuel production. Bioresour. Technol. 2015, 184, 202-214. [CrossRef] [PubMed]

12. Andersson, V.; Viklund, S.B.; Hackl, R.; Karlsson, M.; Berntsson, T. Algae-based biofuel production as part of an industrial cluster. Biomass Bioenergy 2014, 71, 113-124. [CrossRef]

13. Borowitzka, M.A. High-value products from microalgae-Their development and commercialisation. J. Appl. Phycol. 2013, 25, 743-756. [CrossRef]

14. Slade, R.; Bauen, A. Micro-algae cultivation for biofuels: Cost, energy balance, environmental impacts and future prospects. Biomass Bioenergy 2013, 53, 29-38. [CrossRef]

15. Dickinson, S.; Mientus, M.; Frey, D.; Amini-Hajibashi, A.; Ozturk, S.; Shaikh, F.; Sengupta, D.; El-Halwagi, M. A review of biodiesel production from microalgae. Clean Technol. Environ. Policy 2017, 19, 637-668. [CrossRef]

16. Okada, M. Regulations of Wastewater Discharge in Japan. WEPA Workshop, Vientiane, Lao PDR. Available online: http:/ / wepa-db.net/3rd/en/meeting/20160125/pdf/WS1_KeynoteSpeech_ProfOkada160125.pdf (accessed on 25 January 2016).

17. Coons, J.E.; Kalb, D.M.; Dale, T.; Marrone, B.L. Getting to low-cost algal biofuels: A monograph on conventional and cutting-edge harvesting and extraction technologies. Algal Res. 2014, 6, 250-270. [CrossRef]

18. Milledge, J.J.; Heaven, S. A review of the harvesting of microalgae for biofuel production. Rev. Environ. Sci. Biotechnol. 2013, 12, 165-178. [CrossRef]

19. Vandamme, D. Flocculation Based Harvesting Processes for Microalgae Biomass Production. Ph.D. Thesis, KU Leuven, Leuven, Belgium, 2013. Available online: www.vliz.be/imisdocs/publications/254002.pdf (accessed on 5 January 2016).

20. Dong, T.; Knoshaug, E.P.; Pienkos, P.T.; Laurens, L.M.L. Lipid recovery from wet oleaginous microbial biomass for biofuel production: A critical review. Appl. Energy 2016, 177, 879-895. [CrossRef]

21. Smayda, T.J. The suspension and sinking of phytoplankton in the sea. Oceanogr. Mar. Biol. Ann. Rev. 1970, 8, 353-414.

22. Van Ierland, E.T.; Peperzak, L. Separation of marine seston and density determination of marine diatoms by density gradient centrifugation. J. Plankton Res. 1984, 6, 29-44. [CrossRef] 
23. Kromkamp, J.; Walsby, A.E. A computer model of buoyancy and vertical migration in cyanobacteria. J. Plankton Res. 1990, 12, 161-183. [CrossRef]

24. Visser, P.M.; Passarge, J.; Mur, L.R. Modelling vertical migration of the cyanobacterium Microcystis. Hydrobiologia 1997, 349, 99-109. [CrossRef]

25. Hu, W. Dry Weight and Cell Density of Individual Algal and Cyanobacterial Cells for Algae Research and Development. Master's Thesis, The University of Missouri-Columbia, Columbia, MO, USA, 2014. Available online: https:/ / mospace.umsystem.edu/xmlui/bitstream/handle/10355/46477/research.pdf? sequence=1 (accessed on 12 January 2017).

26. Roux, J.M.; Lamotte, H.; Achard, J.L. An Overview of Microalgae Lipid Extraction in a Biorefinery Framework. Energy Procedia 2017, 112, 680-688. [CrossRef]

27. Biller, P.; Sharma, B.K.; Kunwar, B.; Ross, A.B. Hydroprocessing of bio-crude from continuous hydrothermal liquefaction of microalgae. Fuel 2015, 159, 197-205. [CrossRef]

28. Elliott, D.C.; Biller, P.; Ross, A.B.; Schmidt, A.J.; Jones, S.B. Hydrothermal liquefaction of biomass: Developments from batch to continuous process. Bioresour. Technol. 2015, 178, 147-156. [CrossRef] [PubMed]

29. Demura, M.; Yoshida, M.; Yokoyama, A.; Ito, J.; Kobayashi, H.; Kayano, S.; Tamagawa, Y.; Watanobe, M.; Date, N.; Osaka, M.; et al. Biomass productivity of native algal communities in Minamisoma city, Fukushima Prefecture, Japan. Algal Res. 2018, 29, 22-35. [CrossRef]

30. National Astronomical Observatory of Japan Calendar of Fukushima Prefecture, Japan. Available online: http:/ / eco.mtk.nao.ac.jp/koyomi/dni/dni07.html (accessed on 15 June 2018).

31. Shimamura, R.; Watanabe, S.; Sakakura, Y.; Shiho, M.; Kaya, K.; Watanabe, M.M. Development of Botryococcus seed culture system for future mass culture. Procedia Environ. Sci. 2012, 15, 80-89. [CrossRef]

32. Ptacnik, R.; Andersen, T.; Tamminen, T. Performance of the Redfield Ratio and a Family of Nutrient Limitation Indicators as Thresholds for Phytoplankton N vs. P Limitation. Ecosystems 2010, 13, 1201-1214. [CrossRef]

33. Boelee, N.C.; Temmink, H.; Janssen, M.; Buisman, C.J.N.; Wijffels, R.H. Scenario Analysis of Nutrient Removal from Municipal Wastewater by Microalgal Biofilms. Water 2012, 4, 460-473. [CrossRef]

34. Japan Sewage Works Association. Design Standard for Municipal Wastewater Treatment Plants, 2nd ed.; Japan Sewage Works Association: Tokyo, Japan, 2013; Available online: http:/ /gcus.jp/wp/wp-content/uploads / 2014/06/735735ded23d4d28db9cc4f879e8da24.pdf (accessed on 17 January 2016).

35. Wang, T.; Yabar, H.; Higano, Y. Perspective assessment of algae-based biofuel production using recycled nutrient sources: The case of Japan. Bioresour. Technol. 2013, 128, 688-696. [CrossRef] [PubMed]

36. Redfield, A.C. The Biological Control of Chemical Factors in the Environment. Am. Sci. 1958, 46, $205-221$.

37. Geider, R.J.; La Roche, J. Redfield revisited: Variability of C:N:P in marine microalgae and its biochemical basis. Eur. J. Phycol. 2002, 37, 1-17. [CrossRef]

38. Tohoku Electric Power Group. Environmental Action Report. 2016. Available online: http://www.tohokuepco.co.jp/enviro/tea2016/pdf/2016_all_e.pdf (accessed on 25 December 2016).

39. Posten, C.; Schaubb, G. Microalgae and terrestrial biomass as source for fuels-A process view. J. Biotechnol. 2009, 142, 64-69. [CrossRef] [PubMed]

40. Chisti, Y. Large-Scale Production of Algal Biomass: Raceway Ponds. Algae Biotechnol. 2016, 21-40. [CrossRef]

41. Chen, W.-T.; Zhang, Y.; Zhang, J.; Yu, G.; Schideman, L.C.; Zhang, P.; Minarick, M. Hydrothermal liquefaction of mixed-culture algal biomass from wastewater treatment system into bio-crude oil. Bioresour. Technol. 2014, 152, 130-139. [CrossRef] [PubMed]

42. Jones, S.; Davis, R.; Zhu, Y.; Kinchin, C.; Anderson, D.; Hallen, R.; Elliott, D.; Schmidt, A.; Albrecht, K.; Hart, T.; et al. Process Design and Economics for the Conversion of Algal Biomass to Hydrocarbons: Whole Algae Hydrothermal Liquefaction and Upgrading; U.S. Department of Energy: Richland, WA, USA, 2014. Available online: http:/ / www.pnnl.gov/main/publications / external/technical_reports/PNNL-23227.pdf (accessed on 3 January 2016).

43. Vardon, D.R. Hydrothermal Liquefaction for Energy Recovery from High-Moisture Waste Biomass. Master's Thesis, The University of Illinois at Urbana-Champaign, Champaign, IL, USA, 2012. Available online: https: / / www.ideals.illinois.edu/bitstream/handle/2142/34327 /Vardon_Derek.pdf?sequence=1 (accessed on 2 January 2015).

44. De Bhowmick, G.; Koduru, L.; Sen, R. Metabolic pathway engineering towards enhancing microalgal lipid biosynthesis for biofuel application-A review. Renew. Sustain. Energy Rev. 2015, 50, 1239-1253. [CrossRef] 
45. Weyer, K.M.; Bush, D.R.; Darzins, A.; Willson, B.D. Theoretical Maximum Algal Oil Production. Bioenergy Res. 2010, 3, 204-213. [CrossRef]

46. Rogers, J.N.; Rosenberg, J.N.; Guzman, B.J.; Oh, V.H.; Mimbela, L.E.; Ghassemi, A.; Betenbaugh, M.J.; Oyler, G.A.; Donohue, M.D. A critical analysis of paddlewheel-driven raceway ponds for algal biofuel production at commercial scales. Algal Res. 2014, 4, 76-88. [CrossRef]

47. Pittman, J.K.; Dean, A.P.; Osundeko, O. The potential of sustainable algal biofuel production using wastewater resources. Bioresour. Technol. 2011, 102, 17-25. [CrossRef] [PubMed]

48. Wiley, P.E.; Campbell, E.J.; McKuin, B. Production of Biodiesel and Biogas from Algae: A Review of Process Train Options. Water Environ. Res. 2011, 83, 326-338. [CrossRef] [PubMed]

49. Ramirez, J.A.; Brown, R.J.; Rainey, T.J. A review of hydrothermal liquefaction bio-crude properties and prospects for upgrading to transportation fuels. Energies 2015, 8, 6765-6794. [CrossRef]

50. Biller, P.; Ross, A.B.; Skill, S.C.; Lea-Langton, A.; Balasundaram, B.; Hall, C.; Riley, R.; Llewellyn, C.A. Nutrient recycling of aqueous phase for microalgae cultivation from the hydrothermal liquefaction process. Algal Res. 2012, 1, 70-76. [CrossRef]

51. Barreiro, D.L.; Prins, W.; Ronsse, F.; Brilman, W. Hydrothermal liquefaction (HTL) of microalgae for biofuel production: State of the art review and future prospects. Biomass Bioenergy 2013, 53, 113-127. [CrossRef]

52. Singh, S.P.; Singh, P. Effect of $\mathrm{CO}_{2}$ concentration on algal growth: A review. Renew. Sustain. Energy Rev. 2014, 38, 172-179. [CrossRef]

53. Zhang, X. Microalgae Removal of $\mathrm{CO}_{2}$ from Flue Gas; IEA Clean Coal Centre: London, UK, 2015; Available online: https://www.usea.org/sites/default/files/042015_Microalgae\%20removal\%20of\%20CO2\%20from\% 20flue\%20gas_ccc250.pdf (accessed on 8 January 2016).

54. Iasimone, F.; de Felice, V.; Panico, A.; Pirozzi, F. Experimental study for the reduction of $\mathrm{CO}_{2}$ emissions in wastewater treatment plant using microalgal cultivation. J. $\mathrm{CO}_{2}$ Util. 2017, 22, 1-8. [CrossRef]

55. Chia, S.R.; Ong, H.C.; Chew, K.W.; Show, P.L.; Phang, S.-M.; Ling, T.C.; Nagarajan, D.; Lee, D.-J.; Chang, J.-S. Sustainable approaches for algae utilisation in bioenergy production. Renew. Energy 2017, 1-15. [CrossRef]

56. Selvaratnam, T.; Pegallapati, A.; Montelya, F.; Rodriguez, G.; Nirmalakhandan, N.; Lammers, P.J.; van Voorhies, W. Feasibility of algal systems for sustainable wastewater treatment. Renew. Energy 2015, 82, 71-76. [CrossRef]

57. Collet, P.; Lardon, L.; Helias, A.; Bricout, S.; Lombaert-Valot, I.; Perrier, B.; Lepine, O.; Steyer, J.-P.; Bernard, O. Biodiesel from microalgae-Life cycle assessment and recommendations for potential improvements. Renew. Energy 2014, 71, 525-533. [CrossRef] 